\title{
Review of offshore energy in Malaysia and floating Spar platform for sustainable exploration
}

\author{
A.B.M. Saiful Islam*, Mohammed Jameel, Mohd Zamin Jumaat, S.M. Shirazi, Firas A. Salman \\ Department of Civil Engineering, Faculty of Engineering, University of Malaya, 50603 Kuala Lumpur, Malaysia
}

\section{A R T I C L E I N F O}

\section{Article history:}

Received 22 August 2011

Received in revised form

30 June 2012

Accepted 15 July 2012

Available online 30 August 2012

\section{Keywords:}

Energy reserve

Oil and natural gas exploration

Malaysian deep water

Sedimentary basins

Offshore floating structures

Spar platform

\begin{abstract}
A B S T R A C T
Rapidly rising trends of fuel consumption indicate enormous energy crisis of global proportions in near future. Following the trend, Malaysia's fuel consumption has been increasing by an annual rate of $7.2 \%$ since 1990 and has even reached 44.9 Mtoe in 2008. It is forecasted to reach 207.3 Mtoe by the year 2030. Due to serious depletion of reserves in various onshore locations, the exploration process is expanded to offshore deeper waters. Seven sedimentary basins belonging to Malaysia, in South China Sea, show great promise to be excellent sources of hydrocarbons. For deep-sea exploration fixed offshore structures are not feasible. An economical alternative is Spar platforms, which are floating structures ideal for exploration of deep water deposits. In this research, Malaysian experience in offshore hydrocarbon exploration is investigated. Various kinds of operational Spar platforms are censoriously explored and their recent technical developments are reviewed. The study reveals that Malaysia's primary energy requirements were met (in year 2008) with natural gas by $43.4 \%$ of the total, crude oil by $38.2 \%$, coal by $15.3 \%$ and hydropower by $3.1 \%$; indicating evidently that natural gas and crude oil are still the predominant energy sources. Out of the total energy, around $70 \%$ oil and $85 \%$ natural gas come from offshore fields. These large figures highlight the necessity to consider economically viable alternatives. Spar platform is an innovative marine structure designed to conduct such deep sea explorations. First commissioned Spar at Kikeh field of Malaysia is testimony to immense potential and possibilities of incorporating Spar platforms in the country's deep reserves for sustainable energy generation. Classic Spar, Truss Spar, Cell Spar and Cell-truss Spar are identified to be well suited for these environments. Since the offshore fields are located at waters with more than $1000 \mathrm{~m}$ depth, Spar platforms can be successfully installed at these Malaysian deep water fields.
\end{abstract}

(c) 2012 Elsevier Ltd. All rights reserved.

\section{Contents}

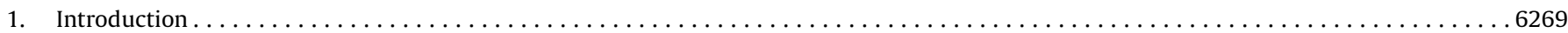

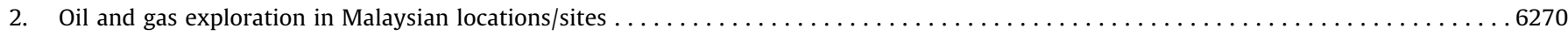

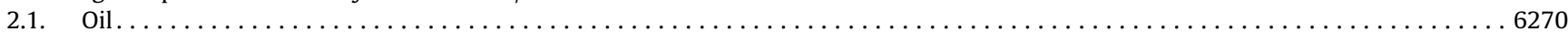

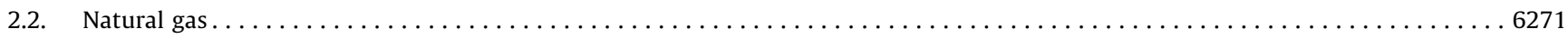

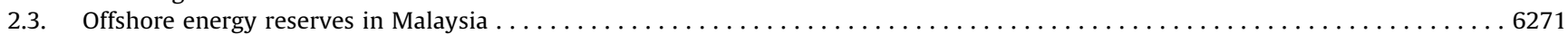

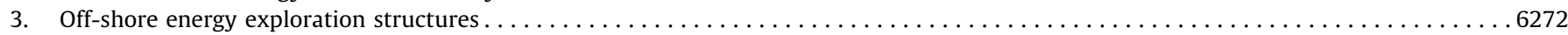

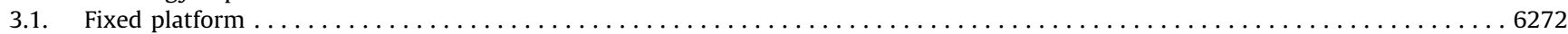

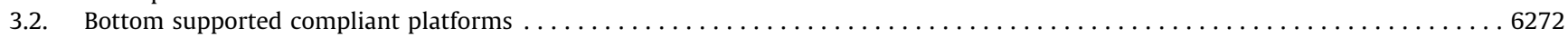

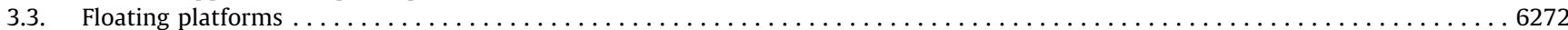

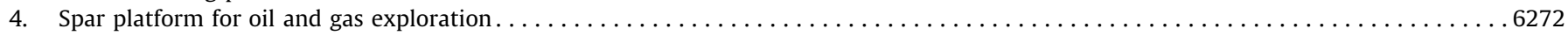

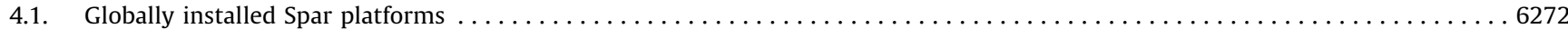

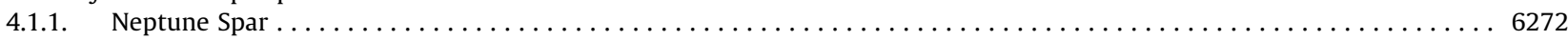

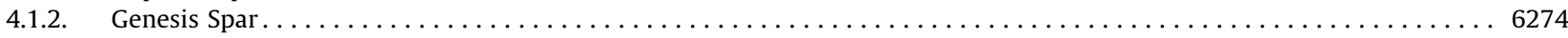

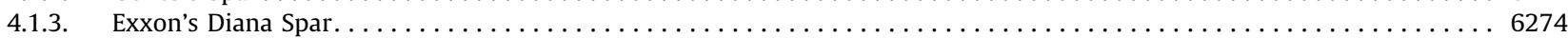

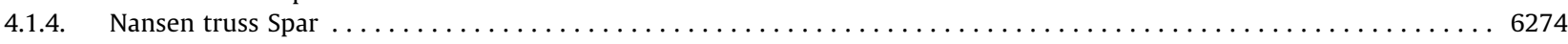

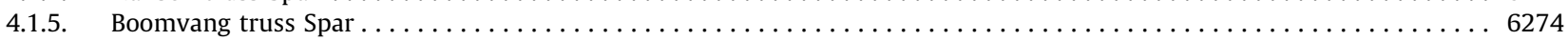

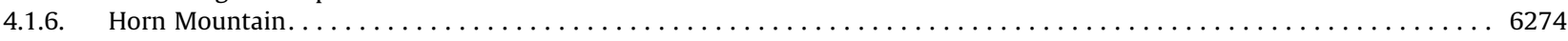

\footnotetext{
* Corresponding author. Tel.: +60 102573287; fax: +60 379675318.

E-mail address: abm.saiful@gmail.com (A.B.M.S. Islam).
} 


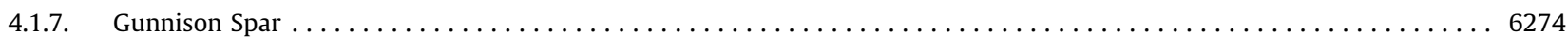

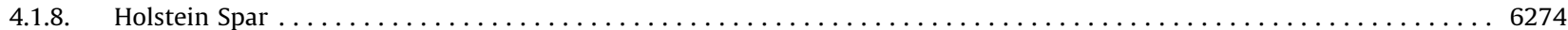

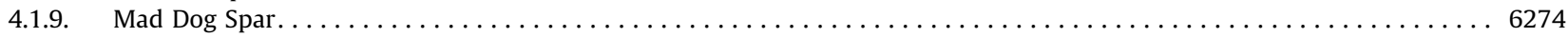

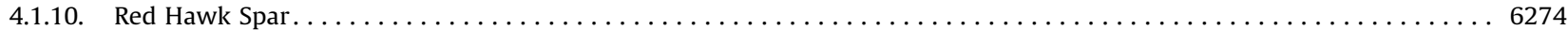

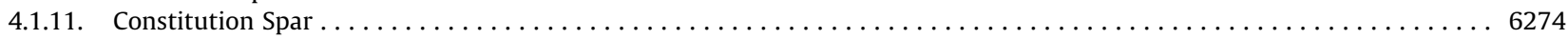

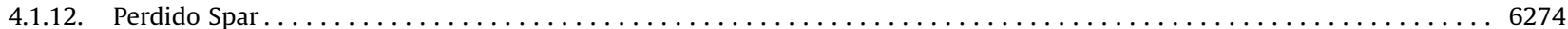

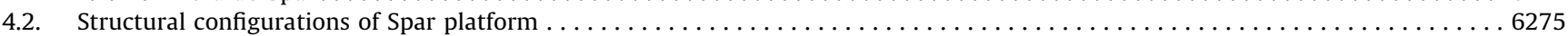

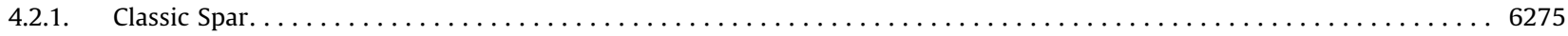

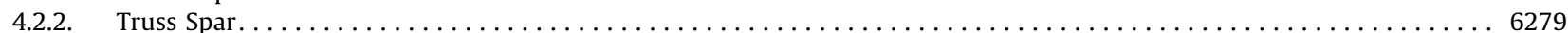

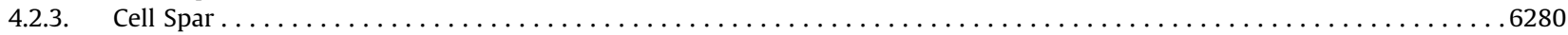

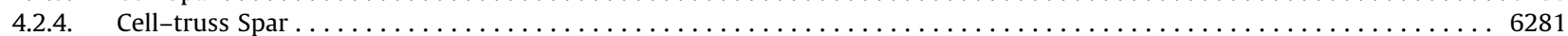

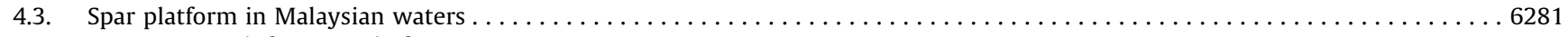

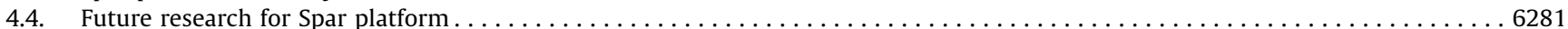

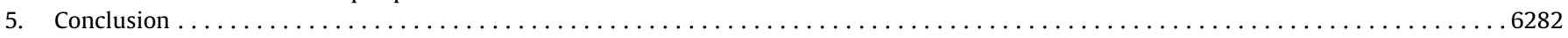

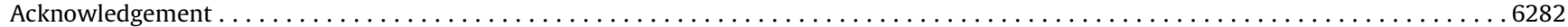

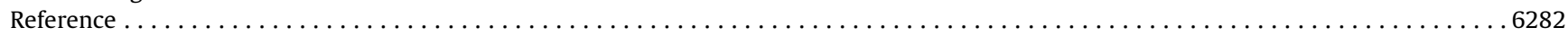

\section{Introduction}

Over the past few decades, a drastic increase in the demand for energy, specifically oil and natural gas, has become evident worldwide. The global consumption of fuel reached 11,295 million tons of oil equivalent (Mtoe) in 2008 which is double the amount of the meagre 6630 Mtoe in 1980 [1]. This rising trend forecasts the global energy demand in the year 2030 to increase by a shocking $53 \%$ equivalent to 17,282 Mtoe. Among the primary sources of energy (Fig. 1) oil and natural gas account for the major share, with around $34.8 \%$ and $24.1 \%$ respectively in the year 2008 (Table 1).Although there has been a significant development and advancement in the discovery and research of alternative and renewable energy generation sources [2-7], it is still very negligible in the face of dramatically increasing demand.

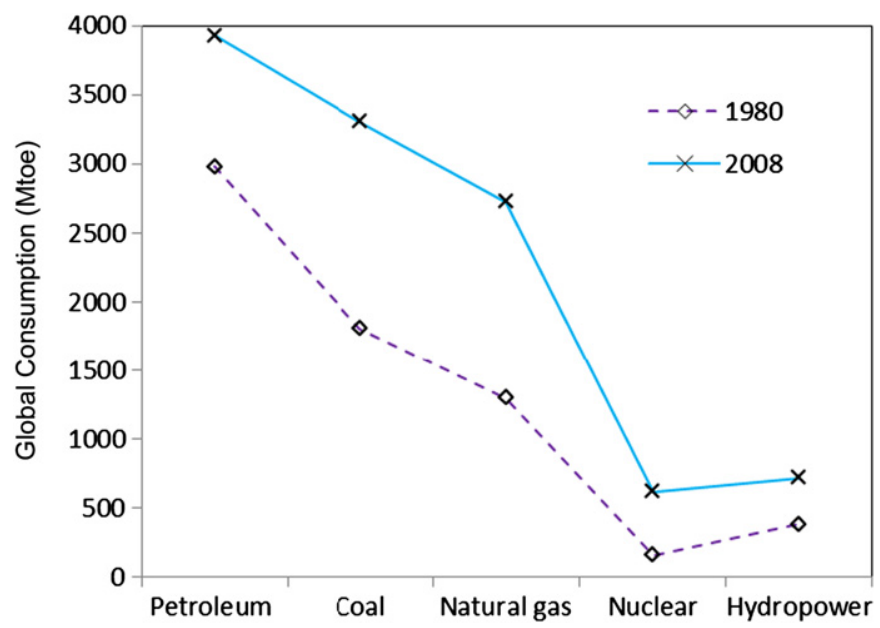

Fig. 1. Increment of global primary energy consumption.

Table 1

Comparison of global primary energy consumption.

\begin{tabular}{|c|c|c|}
\hline Source & $\begin{array}{l}1980 \text { (Total } 6629.8 \text { Mtoe) } \\
\text { Share (\%) }\end{array}$ & $\begin{array}{l}2008 \text { (Total } 11294.9 \text { Mtoe) } \\
\text { Share (\%) }\end{array}$ \\
\hline Oil & 44.9 & 34.8 \\
\hline Coal & 27.3 & 29.2 \\
\hline Natural gas & 19.6 & 24.1 \\
\hline Nuclear & 2.4 & 5.5 \\
\hline Hydropower & 5.8 & 6.4 \\
\hline
\end{tabular}

Thus, the elaborate re-examination of the sources and methods of production of oil and gas is of utmost importance in fulfilling the projected energy consumption growth.

Quite predictably, this global trend of excessive energy consumption growth is also reflective of the energy situation in Malaysia. Malaysia's total energy demand has been growing at a significant rate, and is expected to rise even further to record amounts in the future [8]. Fuel consumption alone has increased by $7.2 \%$ per annum since 1990 and has touched 44.9 Mtoe in 2008 , and is forecasted to be 207.3 Mtoe in the year 2030 [9]. However, the energy mix in Malaysia changed with a significant reduction on the reliance for oil, although dependence on natural gas still stands at more than half of the total [10]. Therefore, a thorough study analyzing ways and means to increase the production of oil and gas in the Malaysian region is the need of the hour. It is worth mentioning that the energy status of number of countries has been evaluated suggesting several sources [11-17]. Efficient and effective policies for designing and optimizing the energy scenario and promising technologies for implementation have been proposed [18-21]. Existing research on the energy reserves of Malaysia and the region are still in the infantile stages, especially with respect to strategies on increasing oil and gas production. Significant numbers of studies have suggested and proven that ocean environments can be strategic and lucrative sources of energy [22-28]. The nearby offshore area around South China Sea [29-32] correspondingly supports this possibility for Malaysia. Most of the developing and even developed countries have resorted to exploration of oil and gas reservoirs below the seabed. This global initiative is due to two fundamental factors. Firstly, the steep increase in the prices of oil and gas and their by-products. Secondly, almost every country in the world has realized that the importation of petroleum products is a severe drain on their financial resources. A huge amount of fuel energy can be collected from the sea environments [33-36]. Offshore sedimentary basins of Malaysia can be effective sources of fuel compensation if oil and natural gas production can be optimized from its deep waters.

Under deep water conditions, conventional fixed jacket type off-shore platforms are highly uneconomical and prove to be unsuitable. Research into alternative methods and approaches for deep sea energy exploration has resulted in the development of a series of flexible, compliant structures like the Tethered Buoy Tower (TBT), the Articulated Leg Platform (ALP), the Tension Leg Platform (TLP) etc. The Spar is the latest among this new generation of compliant off-shore structures suitable for ocean drilling, production and storage of oil in deep water $[37,38]$. Several state-of-the art works on Spar platform are available in 
the existing research literature [39,40]. The Spar platform has been regarded as a competitive floating structure for deep and ultra-deep water, oil and gas production [41-43]. Structurally it is a rigid cylinder with six degrees of freedom (dof), anchored to the sea-bottom by vertical or catenary cables. The original idea was to design a simple structure with a natural frequency far below the typical dominant ocean wave frequency-range in order to reduce the resulting dynamic effects. This resulted in an appreciable reduction of wave-induced forced vibrations in the range of frequencies of waves. Therefore, Spar platforms deep water conditions are found to be the most economical and efficient type of off-shore oil drilling platforms.

Malaysia has recently installed its first Spar at the Kikeh field located at $1330 \mathrm{~m}$ water depth off the shores of Sabah, in the year 2007. It is the first Spar ever mounted outside the Gulf of Mexico $[44,45]$. Recently, an increasing interest in utilizing Spar technology for deep and ultra-deep production platforms [46,47] has been observed. The Spar can be installed [48,49] regardless of water depth, number of wells and deck load as its heave natural period is dependent only on the draft of the Spar.

Thus, the objective of this research is to carry out a thorough literature survey and review of up to date research on the oil and gas status in Malaysia, offshore reserves of oil and gas energy, exploration of primary energy from Malaysian deep waters and offshore compliant floating Spar platforms for oil and gas exploration.

\section{Oil and gas exploration in Malaysian locations/sites}

Malaysia has a huge potential to meet the growing energy consumption demand on its own. From the commencement of the last century it has successfully started to acquire and extract oil and natural gas. Since the last 18 years the total primary energy supply has been increased. It was around 64 Mtoe in 2008 reflecting more than a $200 \%$ upturn from the year 1990 [1]. This amount is relatively high, in comparison with other developing countries. However, the consumption scope of fuel energy has been increasing considerably as a result of fast paced urbanization and industrialization. As per the energy data for the Malaysian region [50], Malaysia is a significant net exporter of oil and also the leading exporter of liquefied natural gas (LNG) to the world, ranking second in the world, behind Qatar.

Malaysia's first ever oil well was discovered on Canada Hill in Miri, Sarawak in the year 1910. After the Miri land field discovery, there was no looking back as exploration and production activity stepped up and covered the entire Sarawak land mass and was subsequently followed by the exploration of Sabah and Terengganu waters. To date, oil and later the discoveries of gas fields have propelled and fuelled the socio-economic development of the country and its people for about 100 years, with contribution to the Government totalling RM403.3bil between 1974 and 2008.

Malaysian energy remained highly reliant only on one prime energy source - oil - before 1980 . This trend was interrupted due to two international oil crises and dramatic jumps in prices in 1973 and 1979 [51]. Therefore, the Four Fuel Diversification
Policy was designed and implemented in the country to deal with the crisis. However, natural gas has turned out to be the leading contributor of total energy supply. Malaysia has also adopted the Five-Fuel Diversification Strategy energy mix devised in the year 1999. According to the embraced strategy, the energy mix in this region is composed of five main sources viz. natural gas, coal, oil, hydro and renewable energy. In the year 2008, the supply of primary energy was contributed by natural gas, crude oil, coal in the portion of $43.4 \%, 38.2 \%, 15.3 \%$ and $3.1 \%$ respectively. It is evident for the aforementioned figures that crude oil and natural gas are the dominant sources of primary energy till date.

\subsection{Oil}

Malaysia possesses 5.46 billion barrels of oil reserves as of January 2008 [52]. The primary reserves are located in the east of Malaysia viz. offshore Sabah and Sarawak. They account for up to $68 \%$ [53] of total reserves. Numerous new projects for oil production have come into operation in the past few years. As of 2008, Malaysia's oil production was reported to be 727,000 [54] barrels/day (bbl/d).

The existing five operational oil refinery facilities in Malaysia produce a total amount of 59,200 barrels per day (Table 2). The biggest refinery is capable of producing 155 thousand barrels per day, and is located at Port Dickson, Negeri Sembilan. It is operated by SHELL Refining Co. (FOM) Bhd. Petroleam Nasional Berhad (PETRONAS), the state-owned national oil company of Malaysia leads the upstream and downstream activities of the oil industry of the nation. PETRONAS operates three refineries with an overall capacity of 259,000 bbl/d. Apart from this, Shell and ExxonMobil operate one plant each with $200,000 \mathrm{bbl} / \mathrm{d}$ and $88,000 \mathrm{bbl} / \mathrm{d}$ capacity respectively. A lot of investment has been made in refinery activities in Malaysia during the last 20 years. The country is now capable of meeting the domestic demand for petroleum products domestically subsequently ending a long dependency on Singaporean refining industries.

To date, the oil production capacity of Malaysia is significantly more than the consumption demand. This ensures that Malaysia possesses a huge oil exporting capability. Fig. 2 illustrates the consumption, production and net export pattern for Malaysian

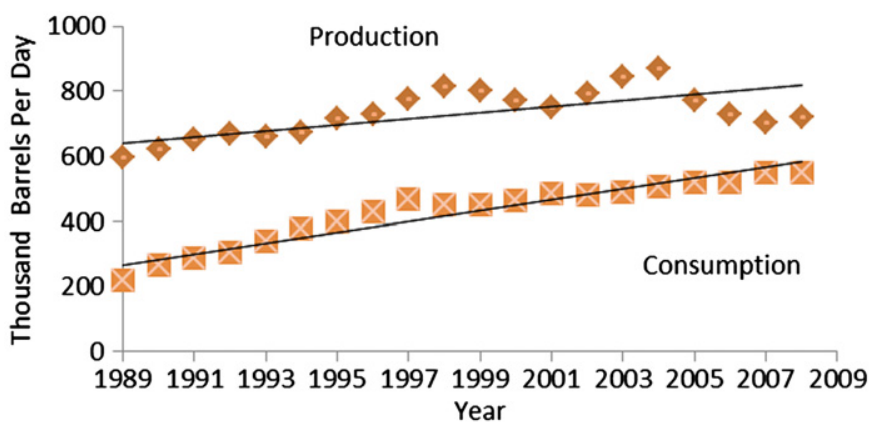

Fig. 2. Malaysian oil production and consumption.

Table 2

On-going oil refinery facilities of Malaysia.

\begin{tabular}{llr}
\hline Oil company & Location & Start-up date \\
\hline SHELL Refining Co. (FOM) Bhd & Port Dickson, Negeri Sembilan & 1963 \\
ESSO Malaysia Bhd & Port Dickson, Negeri Sembilan & 1960 \\
PETRONAS & Kertih, Terengganu & 155,000 \\
PETRONAS & Melaka & 1983 \\
Malaysia Refining Company Sdn Bhd (PETRONAS/ConocoPhillips) & Melaka & 1994 \\
\end{tabular}


oil. It is observed that oil consumption is increasing gradually at steeper fashion than the production. The rising pattern of consumption is reflected to be significant. However, the production growth is observed to be average as depicted in the illustration.

Fig. 2 clearly demonstrates that the rate of rising production is declining faster than the growth rate of consumption. Partly driven by the ever increasing demands for energy worldwide and new technological breakthroughs, the industry continues to flourish as new fields are discovered and brought into production faster and with improved oil recovery.

\subsection{Natural gas}

Malaysia's energy status has seen natural gas, which has been discovered in abundant amounts, as the leading energy source from the early 2000s. From its initial discovery in 1983, its share in the energy mix has grown remarkably, substituting oil as the major source of energy. In January 2008, the country possessed 88 trillion cubic feet (tcf) equivalent as 2.49 trillion cubic metre (tcm) of proven natural gas reserves [52]. Malaysian natural gas reserves are the most prominent in the entire South East Asian region, and even rank 12th largest in the world. Natural gas exploration has grown progressively in recent years. It reached 198 million m/day in 2008 reflecting a 22\% increase since 2002 . Furthermore, domestic consumption of natural gas has increased noticeably as well to 941.6 billion cubic metres in 2008. Additionally, Malaysia is a substantial natural gas exporter, especially of liquefied natural gas (LNG). The country exported 21.2 MMt of LNG in 2005 which is $15 \%$ of total world LNG exports.

The largest amounts of natural gas are extracted from East Malaysia, particularly offshore Sarawak. Malaysia has three LNG processing plants. Each plant is located in a massive complex at Bintulu (East Malaysia-Sarwak). They are supplied from the natural gas fields off the shores of Sarawak. The Bintulu facility is renowned to be the biggest LNG facility in the world, possessing a total liquefaction capability of 22.7 MMt which is equivalent to 1.1 tcf (31 billion cubic metres) per annum. However, the consumption of gas drastically increased from 2.5 million tons in 1990 to about 25 million tons in 2008, after the implementation of the Malaysian fuel diversification strategy.

In Asia, Malaysia possesses one of the most extensive gas pipeline networks. This is owing to the multi-phased Peninsular Gas Utilization (PGU) project which was completed in 1998. The goal of PGU is to expand the infrastructure for natural gas transmission on Peninsular Malaysia. It spans more than 880 miles with 56.7 million cubic metres per day of natural gas transporting capacity. The PGU successfully expanded regional natural gas trade even beyond the domestic consumption.

Malaysia had already piped natural gas to Indonesia and Singapore. In addition, in 2006, construction of the Trans-Thailand-Malaysia Gas Pipeline System was completed. This system permits Malaysia to pipe natural gas to its domestic pipeline system from the Malaysia-Thailand JDA. Furthermore, the planned Trans-ASEAN Gas Pipeline (TAGP) system visualizes a transnational pipeline network establishment connecting the leading natural gas producers with consumers across South East Asia. The extensive infrastructure and its strategic location indicate that Malaysia is designated to serve as a regional hub in the anticipated TAGP project [55].

According to the estimated reserves and production ratio, natural gas will still contribute to the energy mix as the prime energy source for succeeding decades. Till date, about $80 \%$ of Malaysian energy mix is comprised of natural gas. PETRONAS is also dominating the natural gas sector as the oil zone.

As illustrated in Fig. 3, Malaysia's gas production has seen a steady growth over the past 20 years, more so for LNG which has become a major export commodity for the country, at $2.3 \mathrm{tcf}$ ( 64.82 billion cubic metre s) in 2007. The rising consumption of natural gas in Malaysia is portrayed in the aforesaid relation.

The rising pattern of consumption is reflected as sharper than the production. Apart from this, gas production has been observed to be growing at a weighty rate as depicted in the display. It means that the rate of growth in production of natural gas is clearly more than the growth rate of consumption. Thus, it necessitates increased efforts to raise natural gas production domestically.

\subsection{Offshore energy reserves in Malaysia}

Almost all of Malaysia's oil and gas are extracted from offshore energy fields. The sedimentary basins have potential oil and gas reservoirs as they contain many faults and natural traps, which collect and accumulate hydrocarbons under their impermeable layer. As shown in Fig. 4, the continental shelf offshore of Malaysian waters is divided into seven sedimentary basins, out of which three basins have major on-going oil and gas exploration and production activity, namely Malay basin in West Malaysia off Terengganu, Sarawak basin off the East Malaysian state Sarawak, and Sabah basins off the East Malaysian state Sabah. The Malay basin constitutes a major portion of the nation's oil reserves. The basin produces high quality fuel. The benchmark crude oil of Malaysia, Tapis Blend, is very light with a sulphur content of $0.08 \%$ by weight and an API gravity of $44^{\circ}$. Approximately $50 \%$ of the aforementioned Malaysian oil production takes place in the Tapis field.

Since the year 2002, there has been great focus on deep-water fields on the eastern continental shelf. This has translated into high functioning costs and the requirement of extensive technical expertise. The newly adopted oil production project still in the planning and construction phase includes the Gumusut/Kakap

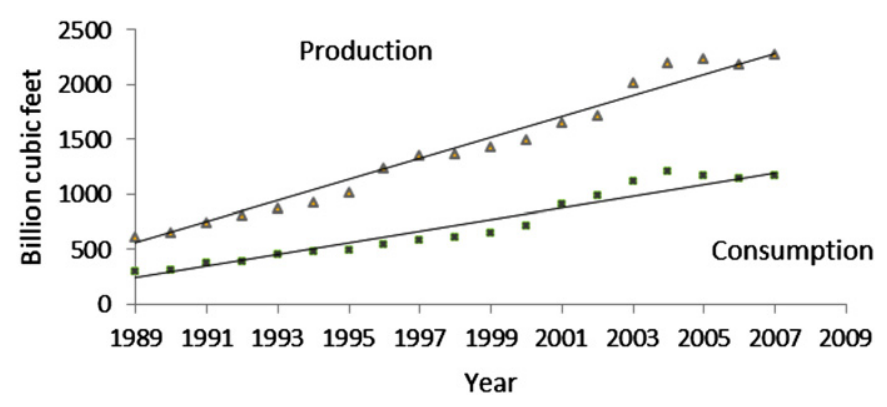

Fig. 3. Malaysian natural gas production and consumption.

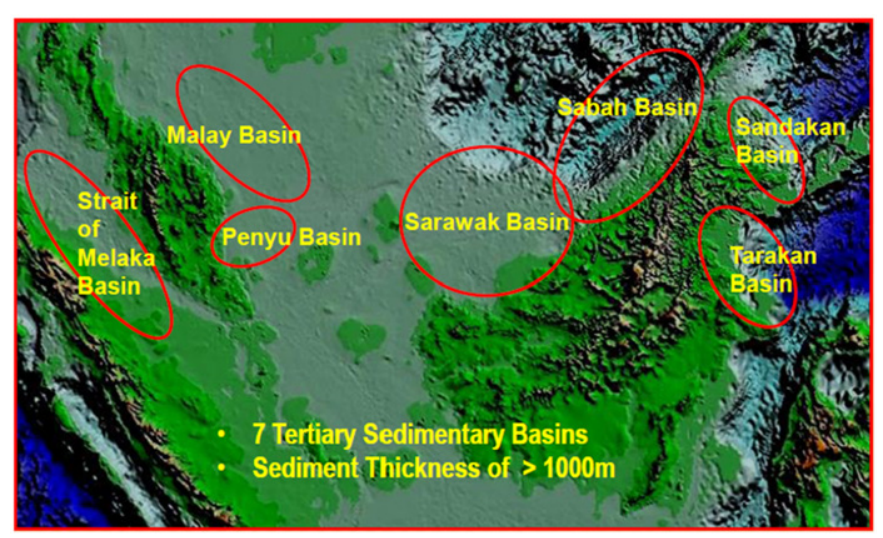

Fig. 4. Sedimentary basins of Malaysia [118]. 
Table 3

Malaysian deep-water fields in appraisal/operation.

\begin{tabular}{llll}
\hline Field name & Recoverable & Onstream date & Operator \\
\hline Kikeh & $536 \mathrm{mmboe}$ & Q2/Q3 2007 & Murphy Oil \\
Gumusut/Kakap & $620 \mathrm{mmboe}$ & Q4 2010/ Q1 2011 & Shell \\
Kebabangan & $2.2 \mathrm{tscf}$ & Q3 2011 & Conoco Phillips \\
Jangas & $81 \mathrm{mmboe}$ & Q4 2011 & Murphy Oil \\
Ubah Crest & $215 \mathrm{mmbee}$ & Q2 2012 & Shell \\
Pisangan & $56 \mathrm{mmboe}$ & Q3 2012 & Shell \\
Kamunsu & 2.2 tscf & Q2 2013 & Shell \\
\hline
\end{tabular}

project which is located in offshore Sabah, at $1200 \mathrm{~m}$ water depth. As the oil and gas industry explores and investigates newer locations and ways to recover hydrocarbons, exploration and production activity has seen itself heading towards greater frontiers. In other words, deeper and deeper wells are being drilled and set up, this in turn results in greater challenges for designing and setting up of offshore production facilities. Table 3 expresses the timeline of operation for deep-water projects in Malaysia. It has been noted that Malaysia is already priming itself to be a deep-water operations regional hub.

\section{Off-shore energy exploration structures}

Off-shore oil and gas exploration is technologically far more complicated than on land. The design and the operation of offshore structures have evolved out of extensive theoretical analyses, model testing and practical experience in the scientific disciplines that lead to the exploitation of oil and gas reserves from hydrocarbon reservoirs below the seabed. There are several different alternatives for fixing the platform deck with its equipment to the seabed, in which the static vertical force, as well as the dynamic forces and moments are transferred to the seabed. The gravity foundation is used to transfer the loads directly onto the uppermost layers of soil and the pile foundation is used to transfer the loads to deep soil layers. A brief outline of various types of off-shore platforms existing around the oceans [56-58] is given in the subsequent section.

\subsection{Fixed platform}

Fixed platforms are designed as structures with natural periods well below the dominant wave periods. They have high stiffness and tend to experience relatively small displacements. They use conventional well systems which were developed along with these platforms as the offshore industry matured, making them very economical until a certain water depth. They require minimum possible material and the environmental loads they are exposed to minimum potential area. Examples are Jacket platforms, gravity platforms, hybrid platforms and Jack-up platforms.

\subsection{Bottom supported compliant platforms}

These are compliant structures, which move with wind, wave and current to a limited extent, rather than resisting their effects as a fixed structure, and offer an economic solution to deep-water applications. The bottom supported compliant platforms are attached to the seabed by means of tension legs, guy lines, flexible members or articulated joints. The buoyancy force or the force of elasticity of the axially stressed legs generates the restoring forces. As the system is not very stiff, the fundamental natural frequency remains low. The design becomes technically and economically feasible as it increases the natural periods of the structure to an extent that the commonly occurring storm wave period is much below the natural periods of the structure. The relative fluid motion is reduced as the magnitude of wave forces acting on the structure becomes smaller. Examples are Guyed towers, Buoyant tower, Flexible tower, Compliant piled tower, Articulated towers, Hybrid compliant platform, Tension leg platforms and Tension buoyant tower.

\subsection{Floating platforms}

For much deeper water operations, the fixed and bottom supported complaint platform is not suitable, and therefore several innovative floating platform design concepts, such as drill ships, semi-submersibles, Spar platforms, floating towers, floating jacket, and deep draft caisson vessel have been proposed. These platforms are economically efficient so as to be installed in deepwater because of less structural weight compared to other types of traditional platforms [59]. These types of structures resist loads by undergoing large excursion, when subjected to environmental loads thereby reducing the forces on the structures. They are usually anchored to the seabed with wires, chains or cables in a spread mooring pattern, so that the restoring forces arise from the anchoring systems. The floating production platform is becoming increasingly attractive because of some additional advantages. It can be mobile and used repeatedly specially in case of reservoirs with marginal reserves. The lag time from discovery to first production can be reduced. It can be quickly disconnected permitting passage for extreme conditions, large ice bergs and in addition its design may not be significantly affected by earthquakes and water depth.

\section{Spar platform for oil and gas exploration}

The viability and feasibility of Spar as a stable floating ocean platform has been recognized for years. The FLIP ship was built in 1962 as a stable platform for oceanographic measurements. The potential use of the Spar in the off-shore industry was recognized in the 1970s with the construction of the Royal Dutch Shell's Brent Spar for oil storage and offloading in the North Sea. Research on the vessel was carried out by some oil companies in the mid-1970s, however, further use of the Spar concept did not materialize. It has been proposed as a low cost production facility for remote sub-sea well sites [60]. A number of operational Spar platforms such as Shell's ESSCO Brent Spar, Oryx Neptune Spar, Chevron Genesis Spar, Exxon's Diana Spar etc. in the Gulf of Mexico and the North Sea prove the effectiveness, economy, and success of such platforms in deep water conditions. Some introductions of different types of Spar platforms are provided in the succeeding section.

\subsection{Globally installed Spar platforms}

The details of some of the different types of Spar platforms installed at various places of the world are given below. Fig. 5 illustrates different types of Spar positioned in numerous sea water depths. The water depths, production facilities and structural configurations of the existing Spar are presented in Table 4.

\subsubsection{Neptune Spar}

The Neptune Spar installed at the Gulf of Mexico has a large cylindrical hull that is moored in a vertical direction and is capable of producing $14,000 \mathrm{bbl}$ of oil and $23 \mathrm{Mmcf} / \mathrm{d}$ or $0.7 \mathrm{Mmcm} / \mathrm{d}$ of gas. It is the world's first classic Spar installed in Gulf of Mexico. Its cylinder is separated by three major components: upper section, centre well and keel section. A square centre 
a

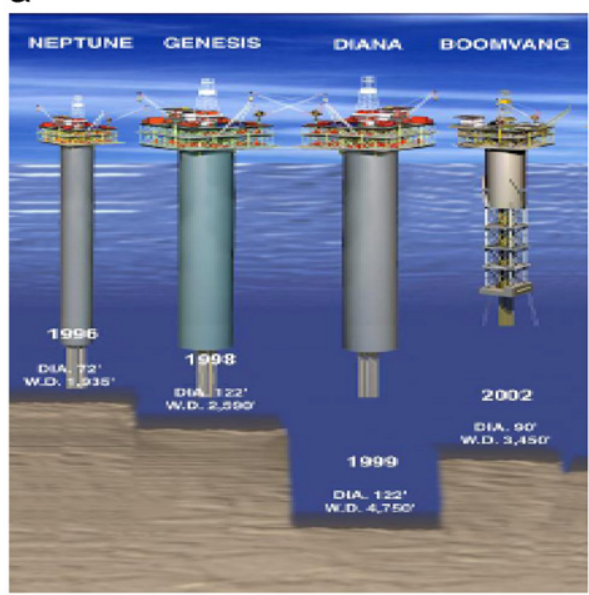

C

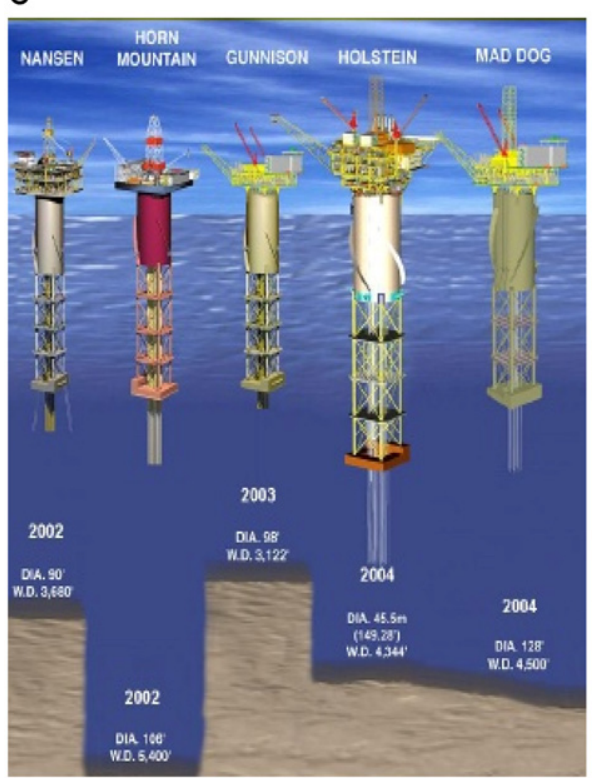

b

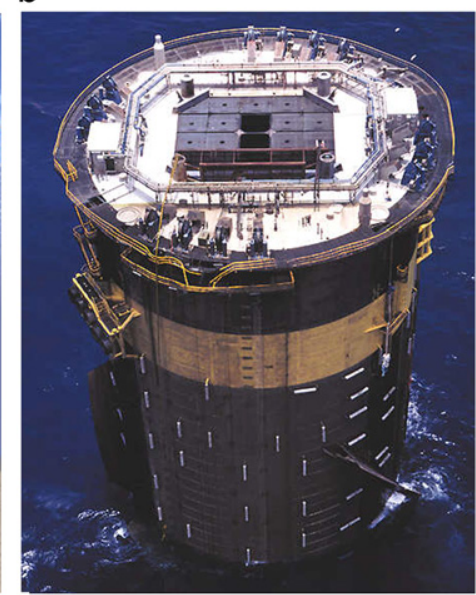

d

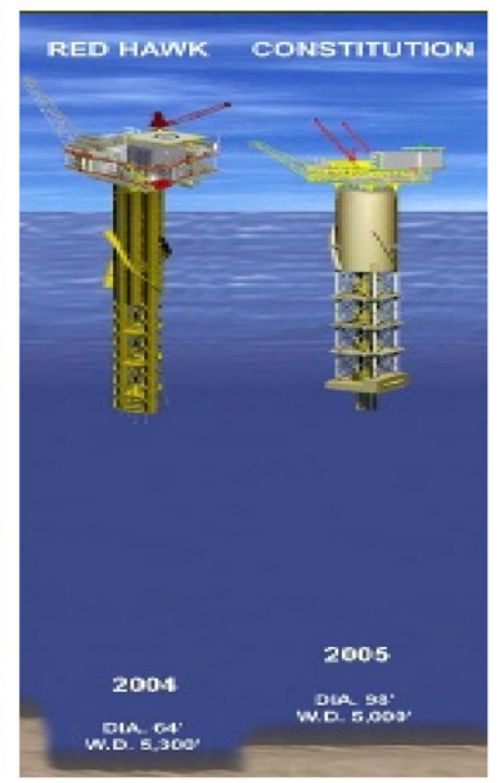

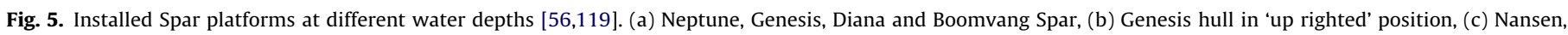
Horn Mountain, Gunnison, Holstien and Mad Dog Spar and (d) Red hawk and Constitution Spar.

Table 4

Installed Spar platforms globally.

\begin{tabular}{|c|c|c|c|c|c|}
\hline \multirow[t]{2}{*}{ Type of Spar } & \multirow[t]{2}{*}{ Water depth (m) } & \multirow[t]{2}{*}{ Location } & \multicolumn{2}{|l|}{ Capacity } & \multirow{2}{*}{$\begin{array}{l}\text { Hull (m) } D=\text { Diameter } \\
L=\text { Length }\end{array}$} \\
\hline & & & bbl/d of oil & $\begin{array}{l}\text { MMcf/d of gas } \\
(\mathrm{MMcm} / \mathrm{d})\end{array}$ & \\
\hline Neptune & 600 & Viosca Knoll Block 826; Gulf of Mexico & 14,000 & $23(0.65)$ & $L=215, D=22$ \\
\hline Genesis & 790 & Green Canyon blocks 160, 161 and 205; Gulf of Mexico & 55,000 & $72(2.04)$ & $L=215, D=37.20$ \\
\hline Exxon's Diana & 1448 & East Breaks Block 945, 946 and 989; Gulf of Mexico & 110,000 & $325(9.21)$ & $L=215, D=37.2$ \\
\hline Nanseen truss & 1130 & East Breaks block 601, 602,646; Gulf of Mexico & 40,000 & $200(5.67)$ & $L=165.5, D=27.4$ \\
\hline Boomvang truss & 1052 & East Breaks block 643; Gulf of Mexico & 40,000 & $200(5.67)$ & $L=165.5, D=27.4$ \\
\hline Horn Mountain & 1646 & Mississippi Canyon Block 126,127; Gulf of Mexico & 65,000 & $68(1.93)$ & $L=178.4, D=32.3$ \\
\hline Gunnison & 952 & Garden Banks Block 668; Gulf of Mexico & 40,000 & $200(5.67)$ & $L=165.5, D=27.4$ \\
\hline Holstein & 1325 & Green Canyon Block 645; Gulf of Mexico & 110,000 & $150(4.25)$ & $L=227, D=46$ \\
\hline Mad Dog & 1372 & Green Canyon Block 782; Gulf of Mexico & 100,000 & $60(1.7)$ & $L=169.2, D=39$ \\
\hline Red Hawk & 1616 & Garden Banks Block 877; Gulf of Mexico & - & $300(8.5)$ & $L=146.4, D=19.5$ \\
\hline Constitution & 1555 & Green Canyon Block 680; Gulf of Mexico & 70,000 & $200(5.67)$ & $L=167.7, D=29.9$ \\
\hline
\end{tabular}

well $9.75 \mathrm{~m} \times 9.75 \mathrm{~m}$ goes through the long buoyant section. In addition, the long tank accommodates 16 well slots at the keel and buoyant section is $90 \mathrm{~m}$ in length. The hull supports an integrated assembly of two production decks with a clear workover deck on top. Station keeping of Spar is done by active six point mooring. Every leg consists of a driven pile, a short length of 
chain, $732 \mathrm{~m}$ of spiral strand wire rope and $320 \mathrm{~m}$ of chain connecting through the fairlead.

\subsubsection{Genesis Spar}

The Chevron's Genesis Spar is the world's first drilling/production Spar located at the Genesis field 150 miles south of New Orleans. The Genesis is the second classic Spar ever assembled in the world. The Spar has four main components: hull, mooring system, risers and topside deck. It is larger than the Neptune Spar and has a full sized drilling rig of $7622 \mathrm{~m}$ depth capability. The field is capable of producing 55,000 barrels of oil along with 2.04 million cubic metre of gas per day. Formally named the Genesis Canyon or Vancouver project, the Genesis field lies in the Viosca Knoll Carbonate Trend. Its freeboard and draft are similar to the Neptune Spar and the buoyant section is $90 \mathrm{~m}$ in length.

\subsubsection{Exxon's Diana Spar}

Exxon's Diana Spar is located at the Gulf of Mexico nearly 150 miles south of Galveston, Texas for full drilling and production. It houses fewer wells than the Chevron Genesis Spar but added production facilities with a centre well of $14.65 \mathrm{~m}$ square. It has a buoyant section which is $106.70 \mathrm{~m}$ in length and an analogous freeboard and draft like Genesis. However, eight legs hold its deck section and it is positioned by 12 moorings. It has well slots comprising of eight productions and one drilling. It has production capabilities of 110 Mbopd and 325 Mmscfpd of gas.

\subsubsection{Nansen truss Spar}

The Nansen truss Spar platform located in the Gulf of Mexico at $3680 \mathrm{~m}$ water depth is the first Spar of its different kind in which the bottom portion of the cylindrical hull is replaced by a tubular truss. It has a production facility for $40,000 \mathrm{bbl}$ of oil and $5.67 \mathrm{MMcm}$ of natural gas per day. It has topside payload of $8750 \mathrm{t}$ and $12,000 \mathrm{t}$ heavy hull connected by nine mooring lines. This Truss Platform was introduced in 2001 when the Nansen was mounted in the Gulf of Mexico. It has three foremost components: (a) hard tank provides most of the in-place buoyancy for the Spar, (2) truss section supports the heave plates and provides separation between the keel tank and hard tank, and (3) keel tank ("Soft Tank") comprises the fixed ballast and works as a natural hang-off location for export pipelines as well as flow lines.

\subsubsection{Boomvang truss Spar}

The Boomvang truss Spar platform is the same as Nansen truss Spar and is the second truss Spar located at East Breaks block 643 in the Gulf of Mexico. The structural specification and capacity of Boomvang truss Spar is the same as Nansen truss Spar.

\subsubsection{Horn Mountain}

Horn Mountain is located at Mississippi Canyon Block 126 and 127 in the Gulf of Mexico. Its Spar hull and submerged portion was imported from Finland along with the topsides with production facility. It is treated as the deepest free-floating dry tree system in the world. Production ramped up to more than $65,000 \mathrm{~b} / \mathrm{d}$ and $1.93 \mathrm{MMcm} / \mathrm{d}$ with seven production wells coming on-stream in 2003. The field is anticipated to eventually recover 150 MMboe.

\subsubsection{Gunnison Spar}

Gunnison Spar was installed at Garden Banks Block 668 in the Gulf of Mexico. The oil well was penetrated to a depth of $5183 \mathrm{~m}$ with Noble Drilling's Noble Amos Runner semi-submersible. Gunnison field incorporating a truss Spar akin to Nansen and Boomvang started producing in December 2003. It acts like a hub with numerous fields including Durango in addition to Dawson spread across a large area. Estimated production is similar to Nansen and Boomvang. However, nine wells were linked with the Spar.

\subsubsection{Holstein Spar}

Holstein Spar incorporated in Green Canyon Block 645 in the Gulf of Mexico is one of the biggest truss Spar hull-mooring system in the whole world. It included the first-ever installation of a Spar-supported riser tension system. The Spar produces $110,000 \mathrm{~b} / \mathrm{d}$ oil and $4.25 \mathrm{MMcm} / \mathrm{g}$ of gas. Holstein Spar is moored by chain, wire, and suction pile anchors. It supports topsides of full operating weights of 26,445 ST approximately. Its drilling rig has a capacity of penetrating for $7622 \mathrm{~m}$. The Spar contains two steel catenary risers. It includes a $15,500 \mathrm{t}$ hard tank $89 \mathrm{~m}$ in length.

\subsubsection{Mad Dog Spar}

Mad Dog Spar was installed in Green Canyon Block 782 in the Gulf of Mexico. It can produce up to $100,000 \mathrm{~b} / \mathrm{d}$ oil and 1.7 MMcm/d of gas. It contains a truss Spar having simultaneous facilities of production and drilling operations and also includes an assimilated drilling rig, dry trees, along with 16 well slots. The Spar can cope with weights of around 18,000 t, which comprise of a drilling rig as well as 126 persons' quarters. The Spar is held with chain-polyester-chain system and moored down by 11 taut mooring

\subsubsection{Red Hawk Spar}

The Cell SPAR Platform, Red Hawk was made operational in 2004. The Red Hawk Spar installed in the Garden Banks Block 877 in the Gulf of Mexico is located at $1616 \mathrm{~m}$ water depth. KerrMcGee developed the field incorporating the world's first cell Spar installed in GOM with permanent use of synthetic moorings. It was designed for a capacity of $8.50 \mathrm{MMcm} / \mathrm{d}$ of natural gas and planned as a host structure of feasible development of neighbouring satellite fields. This innovative Spar considered the third generation of Spar technology, lessens the reserve threshold for cost-effective expansion in deep waters. The Red Hawk cell Spar includes seven $6 \mathrm{~m}$ diameter cylindrical tubes with a centre tube surrounded by them, and linked with structural steel. Each of these tubes encloses variable-ballast tanks and redundant, independent cells. The middle hull section is an extension of three tubes and serves as a rigid link between the hard tank and the keel tank. The lower section named keel surrounds the permanent ballast. Synthetic mooring containing high strength polyester fibre reduces vertical loads on Spar hull in deep water. The separate tubes are attached by heave plates. The heave plates contribute added stability to the structure by reducing the force prone to ocean waves and current.

\subsubsection{Constitution Spar}

The Constitution Spar was installed in the Gulf of Mexico on Green Canyon Block 680. This field was discovered by Kerr-McGee to produce both oil and gas energy. It had been drilled by the semi-submersible Noble Amos Runner. The field incorporates a truss Spar and acts as a regional hub among the area tiebacks. It is capable of producing 70,000 b/d oil and $5.67 \mathrm{MMcm} / \mathrm{d}$ gas.

\subsubsection{Perdido Spar}

Perdido Spar is the most recent Truss Spar installed by Shell. The Spar broke the deep-water record and came in operation in 2010. It is characterized by the tubular members which offer linking between the hard tank and the keel. In addition, the truss system supports to the heave plates which evidently improve stability by lessening heave. 


\subsection{Structural configurations of Spar platform}

The Spar platforms installed in deep water consist of a number of combinations. It is worth mentioning that several types of combinations are being implemented depending on the characteristics and requirements of the different offshore fields. There are four basic approaches of designs for SPAR platforms, namely (1) Classic Spar, (2) Truss Spar, (3) Cell Spar and (4) Cell-Truss Spar. The different Spar designs reflect industry innovations. Each design is an improvement on an older model and offers improved functionality at a reduced cost.

\subsubsection{Classic Spar}

The classic Spar is a Spar platform with a full hull cylinder. It is one of the most versatile types in use. Its cylindrical hull floats vertically in water. The wave action on the surface dampens through the counter balance influence of the net buoyancy of the structure as it floats in much deeper water. The strakes are attached helically around the periphery of the cylinder. This fin like structural element breaks the water flow beside the structure and increases the structural stability. The hull of the classic (full cylinder) Spar consists of three main sections, namely, the upper buoyant, hard tank section, the flooded mid-section which can be configured for oil storage on top of a water cushion and the flooded soft tank section at the keel. Combined with the caisson's deep draught, the entrapped mass of the water in the flooded sections provides a floating structure with very favourable response motions to environmental loadings. For example, typical response periods for Gulf of Mexico Spar are around $350 \mathrm{~s}$ in surge, $60 \mathrm{~s}$ in pitch and $28 \mathrm{~s}$ in heave.

Station keeping is maintained with a multi-component lateral catenary system linked with hull close to its centre of pitch aimed at low dynamic loading. This catenary system consists of 6-20 lines, composed of both chain and wire. As the Spar experiences low motions, it can also incorporate a taut mooring system because of its lower cost, than a full catenary system. The rigid steel production risers are located within the moon pool where the protected water allows each riser to be supported in tension by its own buoyancy module. Although Spar's lateral motions in extreme storms are quite limited, usually $4 \%-8 \%$ of the water depth, the riser does experience noticeable bending at the keel of the vessel and at the seafloor wellhead [56]. Reinforced areas of the production risers where they exit the keel of the hull and where they tie in to the seafloor wellhead accommodate these stresses. The vertical production risers are top tensioned by an assembly of buoyant cylinders through which the well casing strings are tied back ensuring the well is accomplished. In addition, two other categories of risers are used for drilling and export/import function. The export/import risers may be flexible pipe, top tensioned steel pipe or steel catenaries.

The sea floor end of every mooring is anchored by means of a driven pile or suction pile while the hull end runs through a fairlead located well under the water surface and extending up the outside of the hull to chain jacks at the top. Excess chain is stored in the hull. The topside configuration follows typical design practices of fixed platforms. The decks can put up a full drilling rig ( $3000 \mathrm{hp}$ ) or a work-over rig (600-1000 hp) and full production equipment. Because of having low stiffness, the natural frequency is low and the structure moves in the entire six dof viz. surge, sway, heave, roll, pitch and yaw motion (Fig. 6). Due to large displacements, it is imperative to consider the geometric nonlinearity [61-63]. Spar platforms are configured for multiple purposes including production only, or any combination of production, work-over and drilling. The wells can be either directly under the hull and produced through dry trees or can

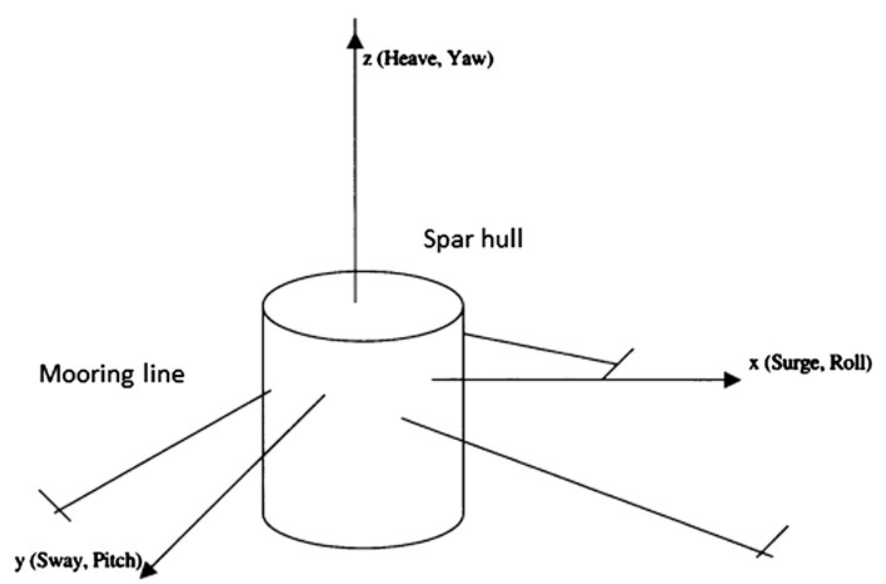

Fig. 6. Spar and 6-degrees of freedom.

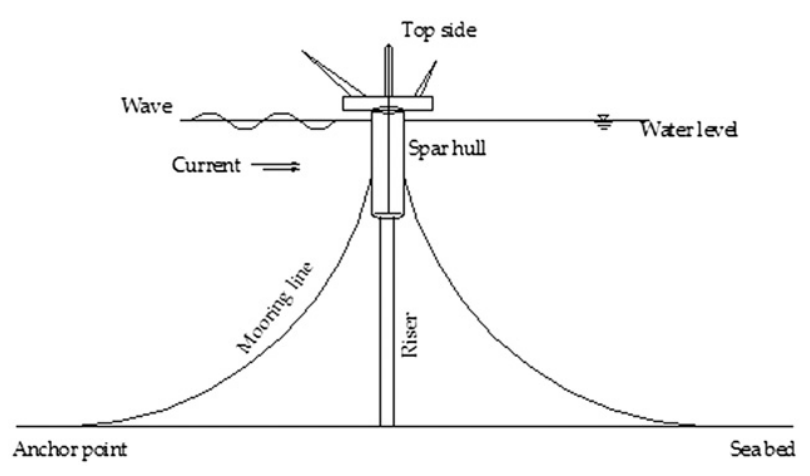

Fig. 7. Sketch of Spar Platform assembly.

be located remote from the vessel and produced through sub-sea trees and flow-lines back to the Spar. Fig. 7 illustrates a typical sketch of the classic Spar platform installed in a deep water region for oil and gas exploration.

4.2.1.1. Analysis technique of classic Spar. The configuration of the floating Spar platform system is habitually the first challenge with its actual behaviour. Evidencing the stable formation is of utmost importance and has to be confirmed in advance of accomplishing the dynamic analyses. The coupled action of the mooring line/ cable/chain with the platform is of complex nature to be attained gradually in actual fashion. It is natural that due to the ideal modelling, the complex solution including nonlinearities experiences difficulty in convergence. Despite the complexities arisen, forces and moments are to be well matched. Succeeding sections describe the approaches dealt with the existing researches on such floating platform assembly.

4.2.1.2. Spar-mooring system. Spar-mooring system is designated by a slackly moored floating structure which usually has very low natural frequency in displacement motion. Due to nonlinear lowfrequency wave forces, the structure will experience large lowfrequency motions. Mooring line damping is from drag forces on mooring lines and the friction between mooring lines and the seabed. Many studies have shown that mooring induced damping could substantially reduce the slow-drift displacement motions of a moored semi-submersible or ship [64-67]. Ran et al. [68] evaluated the response behaviours of a large slack-moored Spar platform subjected to regular and irregular waves. It was concluded that the effects of mooring inertia and damping was 
important to be considered for better prediction of static plus dynamic behaviour of a moored platform. Jha et al. [69] studied the floating Spar buoy platform motions with the wave tank experiments results. Mooring lines were modelled as a set of mass-less linear springs. Wave input and damping were considered in a consistent manner. These successive model refinements are generally found to improve the agreement with the model test results.

Due to different shapes of hulls and different types of mooring systems, motion responses of various structures are quite different. The displacements of a Spar or semi-submersible moored by a spread-mooring system are usually dominated by slow-drift motions, especially in horizontal plan (surge, sway and yaw). While experiencing slow-drift motions in the horizontal plan, a tendon moored platform has high frequency motions in the vertical plan (heave, roll and pitch). Ran and Kim [70] assessed the non-linear response of a tethered/moored Spar platform in the environment of regular as well as irregular waves. A number of experiments with a 1:55 scale model were conducted in the OTRC's deep-water model basin with and without currents and wind. The Spar models used were comparatively smaller than the large one studied by Ran et al. [68]. The small Spar had been supported by a vertical tether and six spread mooring lines. Coupled dynamic analysis results obtained by a developed programme were compared with the uncoupled analysis results.

Chen et al. [71] presented the response of a slack moored Spar platform, to show the coupling phenomenon between Spar and mooring system. The responses were obtained by using a computer code COUPLE and it was compared to corresponding laboratory measurements. COUPLE could be a proper tool for numerical simulation to compensate laboratory experiments, especially for deep waters. The design of a mooring system in unprecedented water depth presents a challenge to the model tests in wave basins. Water depths around $1000 \mathrm{~m}$ can be modelled in the largest test basins in the world by a typical scale ranging from $1: 50$ to $1: 100$ in the past $[72,73]$. Truncated mooring line model tests showed that line dynamic tensions of a truncated mooring system are very different from those of a full-depth (undistorted) mooring system [74]. Ormberg et al. [75] have proposed a hybrid method to extrapolate a truncated mooring model test on the corresponding full-depth mooring line system with the aid of numerical simulations based on a coupled dynamic analysis. Hence, a coupled dynamic analysis is a very useful tool in dealing with a truncated mooring system.

Ran et al. [76] carried out non-linear coupled analysis of a moored Spar platform in random waves. It was assumed that the Spar platform was positioned by four groups of taut catenary mooring lines with three lines in each group. In the analysis, each group of lines was modelled by a single taut catenary mooring line with equivalent material and hydrodynamic properties. The mooring lines were linked with the platform by means of linear as well as rotational springs along with dampers. It was implied that the viscous damping was likely to be overestimated by stochastic linearization. In the presence of collinear currents, the motions of low frequency surge and pitch were appreciably reduced due to the increase in viscous damping. Ma and Patel [77] examined the hydrodynamic dealings of Spar platform under ocean waves and the quantification of those non-linear wave components. Particular attention was given to three force components namely centrifugal force, point force at the Spar bottom end and axial divergence force. The results demonstrated that the centrifugal as well as axial divergence force components could be significant, matched with those of the non-linear forces under wave acceleration. The magnitudes of the two force components were strongly reliant on wave conditions, and could be minor in such environments but could not be neglected.
A coupled dynamic analysis is usually much more accurate than a quasi-static approach in predicting hull motions and mooring line tensions. However, it is also computationally intensive, which hinders its application as a common design tool. Chen et al. [78] carried out the response of Spar platform constrained by slack mooring lines. This study focuses on the cable dynamic analysis and couple dynamic analysis. A coupled dynamic analysis programme called COUPLE applicable to Spars and TLPs, has been developed. COUPLE has two options for computing wave potential forces. Table 5 shows the data used for the study. The reduction of slow drift surge motion due to mooring line damping reached about $10 \%$ at $1018 \mathrm{~m}$ water depth. Mooring tension at wave frequency range anticipated by the coupled dynamic method was eight times more than that at quasi static approach for the same water depth. Such findings were proved to have essential consequences in estimating fatigue strength plus life span of mooring line in deep sea.

Agarwal and Jain [79] carried out a coupled dynamic analysis of Spar platform. The hull was modelled as a six dof based rigid body linked with sea bed by multi-component catenary mooring lines attached with the hull at fairlead position. Numerical studies were performed for numerous regular waves aiming at a detailed parametric study. The coupling of the stiffness matrix played an essential part in the Spar platforms dynamic behaviour. Umar and Datta [80] performed non-linear dynamic investigation of a multipoint slack moored buoy subjected to first and second order wave forces. The hollow cylindrical buoy was attached to the sea floor with six numbers of slack mooring lines. The regular waves were composed of three categories viz, $5 \mathrm{~m} / 5 \mathrm{~s}, 12 \mathrm{~m} / 10 \mathrm{~s}$ and $18 \mathrm{~m} / 15 \mathrm{~s}$. Different types of instability like $n \mathrm{~T}$ sub harmonic oscillations, symmetry breaking bifurcation and aperiodic responses might occur in slack mooring systems. Dynamic conduct of Spar-mooring line structure in time domain and frequency domain was carried out by [81,82]. Fig. 6 idealizes the response directions defined in their study.

Mazaheri and Downie [83] proposed a method based on Artificial Neural Networks (ANN) for the prediction of platform response and mooring forces of floating off-shore structures subjected to multi-varied environments. The designed ANN model had performed the response predictions for determining excursions of a number of platforms subjected to long-term metocean data. Chernetsov and Karlins [84] proposed floating substructures for Stockman gas field in North West Russia. The three proposed sub-structures were Spar-Classic, Spar-Ring and TLPRing. Under ice pressure the Spar and semi-submersible substructures were found to be unsuitable due to their intolerable flexibility. A sub-structure equipped with a "Ring" as a supplement to the vertical column was selected for the study to overcome the problem due to ice pressure. The limitations for the installation required a long period of calm weather conditions for marine operations. Therefore, the SPAR-Ring was the most

Table 5

Mechanical and geometrical properties of Spar-mooring system.

\begin{tabular}{lll}
\hline \multicolumn{3}{c}{ Element properties } \\
\hline \multirow{2}{*}{ Spar (Classic JIP Spar) } & Length & $213.044 \mathrm{~m}$ \\
& Diameter & $40.54 \mathrm{~m}$ \\
& Draft & $198.12 \mathrm{~m}$ \\
& Mass & $2.515276 \mathrm{E} 8 \mathrm{~kg}$ \\
& Mooring Point & $106.62 \mathrm{~m}$ \\
Mooring & No. of Moorings & 4 \\
& Stiffness (EA) & $1.501 \mathrm{E} 9 \mathrm{~N}$ \\
& Length & $2000.0 \mathrm{~m}$ \\
& Mass & $1100 \mathrm{Kg} / \mathrm{m}$ \\
\hline
\end{tabular}


adaptable floating structure for construction in the North West Russian region.

Jameel [56] and Jameel et al. [37] investigated the fully coupled integrated Spar-mooring line system. The large Spar cylinder was physically linked with mooring lines at fairleads provided by six nonlinear springs. Islam et al. [38] followed a similar technique of spar-mooring system. The mooring lines as an integral part of the system support the Spar at fairlead and are pinned at the far end on the seabed. They are partly hanging and partly lying on the sea bed. The sea bed was modelled as a large flat surface with a provision to simulate mooring contact behaviour. The forces on mooring lines due to in sea state were drag, inertia and damping forces. These forces are active concurrently on Spar hull cylinder. The commercial finite element code ABAQUS/ AQUA was used to model the configuration. Modelled Spar-mooring system has been analyzed in effect of proper environmental loading at regular wave. The study also uses data mentioned at Table 5. The model was found to be most ideal. Table 6 specifies the typical statistical analysis results from this research. A brief and standalone sketch of recent advancement on energy exploration structure Spar-mooring line system in different deep water environment has been shown in Table 7.

4.2.1.3. Spar-mooring-riser system. In the case of a Spar platform being installed in deep water, the riser and mooring lines contribute significant inertia and damping. Design of the mooring system and risers connected to Spar platform are dominated by the motion of the Spar platform. An overprediction of motion would require costly risers and mooring lines, while an under-prediction can lead to inadequate design and possibly catastrophic failure. Accurate prediction of motions of Spar platform is very important for the integrity and associated costs of the risers and mooring lines. A detailed survey has been carried out to study the different methodologies adopted by various investigators regarding analysis of the Spar platform.

The boundary conditions at the interfaces between mooring/ tendon/riser systems and the structure should be properly modelled in dynamic analysis. A spring-damper system is usually used for this purpose $[70,85]$. Interfaces between Top Tension Risers (TTRs) and the hull need special considerations. Ormberg

Table 6

Typical dynamic responses in statistical itemization.

\begin{tabular}{|c|c|c|c|c|c|}
\hline & $H_{s}=6 \mathrm{~m}, T_{z}=14 \mathrm{~s}$ & $\operatorname{Max}$ & Min & Mean & Standard deviation \\
\hline Displacement motion & $\begin{array}{l}\text { Surge direction }(\mathrm{m}) \\
\text { Heave direction }(\mathrm{m})\end{array}$ & $\begin{array}{l}16.194 \\
2.374\end{array}$ & $\begin{array}{l}-13.658 \\
-1.981\end{array}$ & $\begin{array}{l}1.038 \\
0.352\end{array}$ & $\begin{array}{l}8.663 \\
1.149\end{array}$ \\
\hline Rotational motion & Pitch direction (rad.) & 0.121 & -0.122 & 0.0001 & 0.074 \\
\hline Tension & $\begin{array}{l}\text { Mooring line } 1(\mathrm{~N}) \\
\text { Mooring line } 3(\mathrm{~N})\end{array}$ & $\begin{array}{l}1.681 \mathrm{E} 7 \\
1.679 \mathrm{E} 7\end{array}$ & $\begin{array}{l}1.583 \mathrm{E} 7 \\
1.574 \mathrm{E} 7\end{array}$ & $\begin{array}{l}1.632 \mathrm{E} 7 \\
1.622 \mathrm{E} 7\end{array}$ & $\begin{array}{l}2.508 \mathrm{E} 5 \\
2.481 \mathrm{E} 5\end{array}$ \\
\hline
\end{tabular}

Table 7

Advancement on Spar-mooring system.

\begin{tabular}{|c|c|c|c|}
\hline Structural configuration & Researchers & Application & Major findings \\
\hline Slack-moored Spar & Ran et al. [68] & Various waves + current & Effects of mooring inertia and damping was substantial \\
\hline $\begin{array}{l}\text { Spar-mooring system. Mooring line as mass- } \\
\text { less linear springs }\end{array}$ & Jha et al. [69] & $\begin{array}{l}\text { Random sea, extreme conditions } \\
\text { in both the Gulf of Mexico and } \\
\text { the North Sea }\end{array}$ & $\begin{array}{l}\text { Refined models added the effect of wave-drift damping and viscous } \\
\text { forces. Consistent choices of damping and wave input were } \\
\text { considered. The model was found to improve good agreement. }\end{array}$ \\
\hline $\begin{array}{l}\text { Tethered/moored Spar. Small Spar supported } \\
\text { by a vertical tether and six spread mooring } \\
\text { lines }\end{array}$ & $\begin{array}{l}\text { Ran and Kim } \\
{[70]}\end{array}$ & Regular+irregular waves & Effects of tethers and mooring lines on hull motions were compared \\
\hline $\begin{array}{l}\text { Slack-moored Spar platform. Spar coupled } \\
\text { with mooring line (taut mooring + springs) }\end{array}$ & $\begin{array}{l}\text { Ran and Kim } \\
{[70]}\end{array}$ & $\begin{array}{l}\text { Steep ocean waves using the } \\
\text { nonlinear Hybrid Wave Model }\end{array}$ & Numerical tool COUPLE was developed as suitable code \\
\hline $\begin{array}{l}\text { Moored Spar platform. Spar positioned with } \\
4 \text { groups of taut catenary mooring lines }\end{array}$ & Ran et al. [76] & Random waves & $\begin{array}{l}\text { In presence of collinear currents, the low frequency surge and pitch } \\
\text { motions appreciably reduces due to the increase in viscous damping }\end{array}$ \\
\hline $\begin{array}{l}\text { Spar platform. Mooring lines replaced by } \\
\text { springs }\end{array}$ & $\begin{array}{l}\text { Ma and Patel } \\
\text { [77] }\end{array}$ & Ocean waves & $\begin{array}{l}\text { Centrifugal and axial divergence force components were strongly } \\
\text { dependent on wave conditions }\end{array}$ \\
\hline $\begin{array}{l}\text { Spar platform constrained by slack mooring } \\
\text { lines (modelled as massless nonlinear } \\
\text { springs) }\end{array}$ & $\begin{array}{l}\text { Chen et al. } \\
{[78]}\end{array}$ & Nonlinear waves & $\begin{array}{l}\text { Coupled dynamic analysis programme COUPLE was developed. } \\
\text { Mooring line tension at coupled dynamic approach were eight times } \\
\text { larger than that quasi static approach }\end{array}$ \\
\hline $\begin{array}{l}\text { Rigid Spar positioned with six multi- } \\
\text { component catenary mooring lines }\end{array}$ & $\begin{array}{l}\text { Agarwal and } \\
\text { Jain }[79,120]\end{array}$ & Several regular waves & $\begin{array}{l}\text { Coupling of the stiffness matrix played an important role in the } \\
\text { dynamic behaviour of Spar platform }\end{array}$ \\
\hline $\begin{array}{l}\text { Multipoint slack moored buoy A hollow } \\
\text { cylindrical buoy anchored to the sea bed } \\
\text { by six slack mooring lines }\end{array}$ & $\begin{array}{l}\text { Umar and } \\
\text { Datta }[80]\end{array}$ & $\begin{array}{l}\text { First and second order wave } \\
\text { forces }\end{array}$ & $\begin{array}{l}\text { Different kinds of instability phenomena like nT sub-harmonic } \\
\text { oscillations, symmetry breaking bifurcation and aperiodic responses } \\
\text { might occur in slack mooring systems }\end{array}$ \\
\hline Spar mooring system & $\begin{array}{l}\text { Sarkar and } \\
\text { Rosset [121] }\end{array}$ & $\begin{array}{l}\text { Wave Model Basin of OTRC in } \\
\text { two bichromatic waves }\end{array}$ & $\begin{array}{l}\text { Two programme developed by OTRC gives similar responses but not } \\
\text { exactly the same }\end{array}$ \\
\hline Floating platform with mooring lines & $\begin{array}{l}\text { Mazaheri and } \\
\text { Downie [83] }\end{array}$ & $\begin{array}{l}\text { Multi-varied environmental } \\
\text { conditions }\end{array}$ & $\begin{array}{l}\text { Conservatism and uncertainties level in traditional methods can be } \\
\text { reduced by ANN and it can be used as a reliable alternative solution } \\
\text { approach }\end{array}$ \\
\hline $\begin{array}{l}\text { Floating substructures Spar-classic, Spar-ring } \\
\text { and TLP-ring }\end{array}$ & $\begin{array}{l}\text { Chernetsov } \\
\text { and Karlinsky } \\
{[84]}\end{array}$ & $\begin{array}{l}\text { Long period of calm weather } \\
\text { condition }\end{array}$ & $\begin{array}{l}\text { SPAR-Ring was the most adaptable floating structure for } \\
\text { construction in the North West Russian region }\end{array}$ \\
\hline $\begin{array}{l}\text { Spar-mooring system Large Spar cylinder } \\
\text { linked with mooring at fairleads by six } \\
\text { nonlinear springs }\end{array}$ & $\begin{array}{l}\text { Jameel et al. } \\
\text { [37], Islam } \\
\text { et al. [38] }\end{array}$ & Regular wave & Mooring line damping was found to be substantial \\
\hline $\begin{array}{l}\text { Spar-mooring system Large Spar cylinder } \\
\text { linked with mooring at fairleads by six } \\
\text { nonlinear springs }\end{array}$ & Jameel [56] & $\begin{array}{l}\text { Regular wave, irregular wave, } \\
\text { long crested random sea, Current }\end{array}$ & Coupled integrated model was found most idealized \\
\hline
\end{tabular}


and Larsen [86] proposed an approach for simultaneous coupled dynamic analysis of floater, mooring and riser system. Turretmoored ship functioning at water depths $150 \mathrm{~m}, 330 \mathrm{~m}$ and $2000 \mathrm{~m}$ were considered. The turret motions, turret forces and line tensions from separated analysis, experiments and coupled analysis were evaluated. There was a good agreement between experiments and coupled analysis outputs.

Irani et al. [87] presented results of wave basin model tests of a Spar platform. The interaction of the risers with the Spar keel plate and the interaction of the buoyancy cans with the Spar hull did not account for the total damping contributions from the risers to the Spar heave response. Estimates of the damping contributions from the buoyancy can/Spar hull interaction were much more than the damping contributions from the riser/keel plate interactions. Cobly et al. [88] presented results of a generic Spar platform subjected to a 100 years extreme hurricane condition. The study attempted to identify the coupling effects by direct comparison of a coupled and decoupled analysis using computer code SIMO. When the coupling of mooring/riser with the vessel response was reinstated, $10-30 \%$ reductions in extremes than de-coupled condition were obtained. The amount of reduction was generally increased with the water depth. Taking the above reductions into consideration the design of mooring/ riser at an early stage in the design could result in significant cost savings.

Gupta et al. [89] developed an analysis tool (ABASIM) to envisage the dynamic conduct of platform, mooring lines and risers. The programme combined ABAQUS and MLTSIM. Coupled response predictions alleviated fears about instability of Spar shapes to long period waves. Response predictions also showed that the heave of a classic Spar could be as low as a truss Spar when additional damping due to mooring lines and risers were considered. Based on results, it was concluded that the current drag on mooring lines and risers could be significant and should be included in the response predictions. Chaudhury and Ho [90] developed an integrated system of risers, mooring lines, and platform in ABAQUS. The dynamic equilibrium of the Spar system and non-linear soil mooring line interaction were taken into account. A non-linear integrated coupled dynamic analysis of floater (NICDAF) was developed, which was shown to predict vessel motion accurately in a fraction of time compared to ABAQUS. Case study results showed that the difference in predicted vessel motions between NICDAF and ABAQUS were negligible for static offset and mostly acceptable for standard deviation of dynamic motion. The mean tensions in the mooring lines could also be predicted fairly well by NICDAF, while the agreement in standard deviation of tension was poor. It was concluded that, for accurate prediction of dynamic motions of risers and mooring lines, full dynamic equilibrium of the risers, mooring lines, and platform system must be maintained. Following the similar work a new method of coupled analysis was developed by Chaudhary [91]. The programme could compute six rigid body motions. The code achieved substantial saving in computational time. For platforms operating in deep-water, the restoring force contributions of risers/ mooring lines were found to be important, hence coupled analysis was recommended to be essential.

Astrup et al. [92] reported the importance of mooring and risers coupling when floating production systems extended to deeper water. For deeper water, the inertial mass, viscous damping, current loading and restoring effects due to both of mooring and riser system are essentially modelled to precisely predict the responses. The coupling effects due to the mooring and riser systems typically tend to reduce the low frequency motion of Spar platform compared to the traditional de-coupled approach. The ability for more accurate prediction of the low frequency Spar motions could consequently contribute to a smaller and economic mooring/riser system ensuring a lighter and economical Spar platform. Kim et al. [93] provided an assessment of the existing industrial capability to predict the responses of several types of deep water floating production systems (TLPs, and SPAR). The scatter in low frequency and high frequency predicted response were generally larger than those in the wave frequency range. Damping caused by the mooring line and risers increased with water depth and had more impact on low frequency responses. The low frequency responses were found to be more important contributors to the total responses as depth increased. The responses were observed to be dependent on the mooring line design, low frequency forces and damping.

Ma and Patel [77] presented an approach based on a newly launched Deep-water Non-linear Coupled Analysis Tool (DeepCAT) for obtaining nonlinear coupled behaviours among platform and moorings/tendons as well as risers. The analysis tool consists of two numerical algorithms. First was the time domain platform motion simulation code (COUNAT) and the second was time domain cable dynamic analysis code (CABLE3D). The results showed large alterations in mean offsets due to coupled and uncoupled analyses for a 100 year loop current condition. The RMS values of the Spar's low frequency motions and tensions in mooring line obtained in coupled analysis were found to be smaller compared to uncoupled programme output. Zhang and Zou [94] dealt with the coupling upshots of risers and supporting guide frames up on hull motions and mooring line dynamics. The resisting moment induced by the contact forces on the support guides and keel joints had significant impact on both the pitch/roll motion and the mooring line tensions. The comparisons showed the enhanced method in use (DeepCAT) was able to simulate the dynamic response of Spar accurately in presence of non-collinear wave, wind, and current. Smaller heave and pitch/roll motions, caused reduction of hull draft and solid ballast in the keel tank. Those reductions had significant impacts on size and weight of hull, mooring lines and risers.

Tahar et al. [95] performed nonlinear coupled hull/mooring/ riser dynamic analyses of a classic Spar, numerical simulations were conducted for 100-yr hurricane environment with nonparallel wind, wave, and current. Several different riser models were investigated. The first model of riser was an elastic rod extended to the keel and free to slide in vertically but constrained at horizontal direction. It was seen that neglecting the portion of riser inside the Spar hull resulted in the over-estimation of the pitch response. The second model of riser consisted of a simple buoyancy-can modelling, which significantly reduced the maximum pitch/roll responses. Ding et al. [96] developed a numerical code (COUPLE) for computing six degrees of freedom of a moored floating platform interacting with its mooring/riser/tendon system dynamically. The computation of potential wave load on a moored structure was carried out based on diffraction wave theory using commercial code WAMIT. The original code CABLE3D was extended for large elongation elements in mooring lines. COUPLED6D had been applied to the study of moored classic Spars and mini TLP. Comparisons with the measurements of the corresponding model tests indicated that it was reliable and effective for the study of a floating off-shore structure dynamically interacting with its mooring/riser/tendon system.

Koo et al. [97] investigated nonlinear multi-contact coupling amongst vertical risers and guide frames through the Spar moonpool. The riser was treated as an elastic rod truncated at the keel position (truncated riser model). Another assembly considered allowed the risers to slide vertically with constant tension keeping constraint horizontally. The truncated riser model neglected the segment of the riser inside the moon-pool which caused overestimation of Spar pitch. The risers were extended inside the moon-pool marinating representative boundary 
conditions. The gap effects among the guide frames and buoyancy-cans were modelled by means of three categories of gap springs. The multi-contact coupling forces among the risers and the riser guide frames had little upshot on Spar displacement motion (surge) and tension in line. Yung et al. [98] carried out a model test for vortex induced vibration (VIV) of Spar hull at David Taylor model basin (DTMB) set at Carderock division in United States naval surface warfare centre. Using the Hoover's Deep draft caisson vessel (DDCV) as an example, it was demonstrated that the developed approach of model test was reliable for VIV assessment. The approach was based on governing physics and did not require factoring of model test results or distortion of model geometry to match field observations. It was a distinct advantage in establishing confidence for the method to be used for future designs. In addition, the VIV test rig and test methodology were also applicable to VIV study of other types of structures.

Kim et al. [99] performed vessel/mooring/riser dynamic coupled analysis using a turret-moored, tanker based FPSO at $1830 \mathrm{~m}$ deep water. The vessel motions and tension in mooring were tested at OTRC wave basin under non-parallel wind-wavecurrent 100-year hurricane environment representative of the Gulf of Mexico. Equivalent truncated mooring system results were evaluated with the OTRC 1:60 model-testing results. It was found that the dynamic mooring tension could be underrated while using the truncated mooring system. Garrett [100] carried out fully coupled analysis of floating vessel-mooring-riser system. Vessel motions were driven by means of environmental forces and restrained by the mooring-systems' forces. The accuracy and efficiency of the measures were illustrated with a large semi-submersible attached by 16 mooring lines as well as 20 risers. It was shown that the progression provided was accurate and efficient.

Rodrigues et al. [101] presented optimized numerical tools aimed at floating platforms' coupled analysis for off-shore oil exploration. The formulation for the spatial as well as time discretization of the structural model intended for the lines was presented. Two domain decomposition approaches were well thought-out. Sub-cycling technique considered the natural partition that existed between the hull and the lines. And the second technique considered the internal decomposition of the mesh of finite elements for representing risers and mooring lines. The methods were devised keeping in view their computerized application with parallel architecture. Low and Langley [102] compared various methods for floating structures' analysis with the rigorous fully coupled analysis in time domain as a yardstick for the accuracy. Two novel methods were presented. The first was an enhancement of the frequency domain approach by a linearization of the geometric nonlinearities. The enhancement was simple and improves the prediction of low frequency vessel response at a minimal computational expense. Nevertheless, there were still discrepancies with the time domain results due to certain limitations. The other method was a hybrid method that simulated the low frequency responses of the coupled system in time domain plus frequency domain for the wave frequency response. The method was found to be almost accurate as fully coupled analysis but required only one-tenth computational strength, even for a geometrically highly nonlinear system.

Tahar and Kim [103] developed a numerical tool for deep water floating platforms anchored by polyester mooring lines. Large elongation as well as nonlinear stress-strain relationships is allowed which was typically observed in polyester fibres. The Rod theory was followed for mooring-line dynamics. Static and dynamic behaviour of a classic Spar with polyester mooring lines and a tensioned buoy were carried out. The mean offset, motions, and tension with polyester lines could be poles apart from the original rod theory result considering linear elastic lines. Low and Langley [104] presented a hybrid approach for coupled analysis in time/frequency domain of vessel/mooring/riser. The vessel was modelled as a six dof consisting of a rigid body. The lines were discretized as lumped masses linked with linear extensional and rotational springs. A good agreement was found for the suggested method with fully coupled time domain analysis, when used for relatively shallow water depths. Low [105] used the same hybrid method to envisage the extreme responses of coupled floating structures. Yang and Kim [106] carried out coupled analysis of hull-tendon-riser for a TLP. The mooring line/riser/tendon system was modelled as an elastic rod. It was connected to the hull with linear and rotational springs. The equilibrium equations of hull and mooring line/risers/tendon system were solved simultaneously. Table 8 illustrates the state of the art development of the Spar-mooring-riser system for energy exploration from deep water.

\subsubsection{Truss Spar}

Truss platforms were introduced by Kerr-McGee in 2001 when the Nansen was mounted in the Gulf of Mexico Truss SPAR Platform. The Truss Spar design has three main components: (1) hard tank, (2) truss section, (3) keel tank. The hard tank delivers the crucial in-place buoyancy intended for the Spar. The truss section offers the separation between the keel tank and hard tank and supports the heave plates. The keel tank ("Soft tank") holds the fixed ballast and entertains as a natural hang-off locality for export pipelines and flow lines. Perdido SPAR Shell's most recent Truss SPAR broke the deep water record and will be operational in 2010. Truss SPARs are characterized by the tubular members that provide a linking between hard tank and keel. The truss system also gives support to the heave plates which improve stability by reducing heave.

Kim et al. [107] performed the non-linear hull/mooring time domain coupled analysis of a truss Spar platform in waves considering collinear steady wind and currents. The results were compared with experimental values and uncoupled analysis. The first and second order wave forces, added mass, radiation damping, and wave drift damping were calculated from a secondorder diffraction/radiation hydrodynamic code, WINTCOL. Time series of total wave force was generated based on a 2-term volterra series model. Hull/mooring coupled dynamics was solved by means of a finite element method based time-domain analysis code, WINPOST. The mooring lines were coupled to the platform by dint of generalized springs and dampers. A case study was accompanied aimed at the Marlin truss Spar with 9 taut mooring lines in $988 \mathrm{~m}$ water depth. The motion and tension spectra in uncoupled analysis with a non-linear mass-less spring was compared with those obtained from fully coupled analysis. It was observed by numerical results that the line dynamics were very important for the mooring design, which was not detected by quasi-static mooring analysis. The large dynamic tension indicated that the dynamic or fatigue analyses should be carried out in a rigorous way for deep water floating platforms with tautleg mooring. The discrepancy between coupled and uncoupled analyses in low frequency motions and tension was small. The coupled analysis capability for such types of complex systems offered the potential to optimize high cost systems. Technical aspects of Truss Spar has been analyzed and studied by a very few researchers $[43,49,107-110]$. This type of structure minimizes the structural volume changing the lower portion of hull into truss. Therefore, the truss Spar is regarded as another competitive and cost-effective floating structure for deep and ultra-deep water oil and gas production. 
Table 8

Advancement of Spar-mooring-riser system.

\begin{tabular}{|c|c|c|c|}
\hline Structural configuration & Researchers & Application & Major findings \\
\hline $\begin{array}{l}\text { Floater-mooring-riser system Turret- } \\
\text { moored ship }\end{array}$ & $\begin{array}{l}\text { Ormberg } \\
\text { and Larsen } \\
{[86]}\end{array}$ & 150 m,330 m,2000 m water depth & $\begin{array}{l}\text { Separate analysis under predicts mean off-set and over } \\
\text { predicts LF motions especially in deep water }\end{array}$ \\
\hline $\begin{array}{l}\text { Spar-buoyancy can-riser Risers attached } \\
\text { at Spar keel plate and can with Spar hull }\end{array}$ & Irani et al. & Wave basin & $\begin{array}{l}\text { Damping contributions from buoyancy can/Spar hull } \\
\text { interaction were much more than damping contributions } \\
\text { from riser keel plate interactions }\end{array}$ \\
\hline Generic Spar platform & $\begin{array}{l}\text { Colby et al. } \\
{[88]}\end{array}$ & 100 years extreme hurricane conditions & $\begin{array}{l}\text { Coupling of mooring and riser system with the vessel } \\
\text { response shows large reductions in extremes in the range of } \\
10 \text { to } 30 \text { per cent compared to de-coupled condition }\end{array}$ \\
\hline Spar platform-mooring lines-risers & $\begin{array}{l}\text { Gupta et al. } \\
\text { [89] }\end{array}$ & $\begin{array}{l}\text { Waves and current. Damping in heave } \\
\text { response included }\end{array}$ & $\begin{array}{l}\text { Analysis tool (ABASIM) was developed to predict the } \\
\text { responses. Current drag on mooring lines and risers could } \\
\text { be significant and should be included in the response } \\
\text { predictions }\end{array}$ \\
\hline $\begin{array}{l}\text { Integrated system of risers, mooring lines } \\
\text { and platform }\end{array}$ & $\begin{array}{l}\text { Chaudhury } \\
\text { and Ho [90] }\end{array}$ & $\begin{array}{l}915 \mathrm{~m}, 1830 \mathrm{~m}, 3050 \mathrm{~m} \text { water depth, Wave } \\
\text { and current }\end{array}$ & $\begin{array}{l}\text { For accurate prediction of dynamic motions of risers and } \\
\text { mooring lines, full dynamic equilibrium of the risers, } \\
\text { mooring lines, and platform system must be maintained. }\end{array}$ \\
\hline Spar-mooring-riser system & $\begin{array}{l}\text { Astrup } \\
\text { et al. [92] }\end{array}$ & $\begin{array}{l}\text { Wind and current excitation, viscous hull and } \\
\text { mooring damping considered }\end{array}$ & $\begin{array}{l}\text { The ability for more accurate prediction of the low } \\
\text { frequency Spar motions could consequently contribute to a } \\
\text { smaller and less expensive mooring and riser system and } \\
\text { hence a lighter and economical Spar platform. }\end{array}$ \\
\hline Spar and TLP & $\begin{array}{l}\text { Kim et al. } \\
{[93]}\end{array}$ & Deep water environment & $\begin{array}{l}\text { The responses were observed to be dependent on the } \\
\text { mooring line design, low frequency forces and damping }\end{array}$ \\
\hline $\begin{array}{l}\text { Integrated coupled system of risers, } \\
\text { mooring lines and platform }\end{array}$ & $\begin{array}{l}\text { Chaudhury } \\
\text { [91] }\end{array}$ & $\begin{array}{l}915 \mathrm{~m}, 1830 \mathrm{~m}, 3050 \mathrm{~m} \text { water depth. Wave and } \\
\text { current }\end{array}$ & $\begin{array}{l}\text { For platforms operating in deep water, the restoring force } \\
\text { contributions of the risers and mooring lines were found to } \\
\text { be important, hence coupled analysis was recommended to } \\
\text { be essential. }\end{array}$ \\
\hline $\begin{array}{l}\text { Hull-mooring-riser-supporting guide } \\
\text { frame }\end{array}$ & $\begin{array}{l}\text { Zhang and } \\
\text { Zou [94] }\end{array}$ & Non-collinear wave, wind, and current & $\begin{array}{l}\text { Performing fully coupled dynamic analysis is recommended } \\
\text { including contact forces to remove unnecessarily } \\
\text { conservative results and to improve the economics of the } \\
\text { field development. }\end{array}$ \\
\hline $\begin{array}{l}\text { Classic Spar Hull/mooring/riser } 14 \text { chain- } \\
\text { polyester-chain mooring lines and } 23 \\
\text { buoyancy can supported vertical risers }\end{array}$ & $\begin{array}{l}\text { Tahar et al. } \\
{[95]}\end{array}$ & $\begin{array}{l}1830 \text { m depth. } 100-y r \text { Hurricane condition } \\
\text { with non-parallel wind, wave, and current }\end{array}$ & $\begin{array}{l}\text { Neglecting the portion of riser inside the Spar hull resulted } \\
\text { in the over-estimation of the pitch response. Riser consisted } \\
\text { of a simple buoyancy-can modelling significantly reduces } \\
\text { the maximum pitch/roll responses. }\end{array}$ \\
\hline $\begin{array}{l}\text { Classic Spar Hull/mooring/riser. } 14 \text { chain- } \\
\text { polyester-chain mooring lines and } 23 \\
\text { buoyancy cans supported vertical risers }\end{array}$ & $\begin{array}{l}\text { Tahar and } \\
\text { Kim [103] }\end{array}$ & $\begin{array}{l}1830 \text { m depth. } 100-y r \text { Hurricane condition } \\
\text { with non-parallel wind, wave, and current }\end{array}$ & $\begin{array}{l}\text { A theory and numerical tool are developed for the coupled- } \\
\text { dynamic analysis of a deep water floating platform with } \\
\text { polyester mooring lines.. It is seen that the mean offset, } \\
\text { motions, and tension with polyester lines can be different } \\
\text { from those by original rod theory with linear elastic lines. }\end{array}$ \\
\hline $\begin{array}{l}\text { Mooring/riser/tendon system. Classic Spar } \\
\text { and TLP }\end{array}$ & $\begin{array}{l}\text { Ding et al. } \\
{[96]}\end{array}$ & Wave, wind & $\begin{array}{l}\text { Corresponding model tests was reliable and effective for } \\
\text { floating off-shore structure dynamically interacting with } \\
\text { mooring/riser/tendon system }\end{array}$ \\
\hline Hull/mooring/riser & $\begin{array}{l}\text { Koo et al. } \\
{[97]}\end{array}$ & $\begin{array}{l}\text { Riser modelled as an elastic rod truncated at } \\
\text { keel and free to slide in vertical and restricted } \\
\text { in horizontal direction }\end{array}$ & $\begin{array}{l}\text { Both pitch and roll motions were reduced significantly } \\
\text { when the effects of the extended risers and buoyancy-cans } \\
\text { inside the moon-pool were considered. The multi-contact } \\
\text { coupling forces between risers and riser guide frames had } \\
\text { little effect on the Spar surge motion and the most loaded } \\
\text { line tension }\end{array}$ \\
\hline $\begin{array}{l}\text { Vessel/mooring/riser. Turret-moored, } \\
\text { tanker based FPSO }\end{array}$ & $\begin{array}{l}\text { Kim et al. } \\
{[99]}\end{array}$ & $\begin{array}{l}\text { 1830m water depth. Wind-wave-current } 100- \\
\text { year hurricane condition in the Gulf of Mexico }\end{array}$ & $\begin{array}{l}\text { The numerically predicted global vessel motions were also } \\
\text { in good agreement with the measurements. It was found } \\
\text { that the dynamic mooring tension could be underestimated } \\
\text { when truncated mooring system was used }\end{array}$ \\
\hline Vessel-mooring-riser & $\begin{array}{l}\text { Garret } \\
{[100]}\end{array}$ & $\begin{array}{l}\text { Vessel motions restrained by mooring and } \\
\text { riser systems }\end{array}$ & $\begin{array}{l}\text { The procedures provided claimed to be accurate and } \\
\text { efficient for fully coupled analysis of floating production } \\
\text { systems }\end{array}$ \\
\hline Hull-mooring-riser & $\begin{array}{l}\text { Rodrigues } \\
\text { et al. [101] }\end{array}$ & $\begin{array}{l}\text { Sub-cycling technique and internal } \\
\text { decomposition technique considered }\end{array}$ & $\begin{array}{l}\text { The methods were devised keeping in view their } \\
\text { implementation in computers with parallel architecture }\end{array}$ \\
\hline Floater/Mooring/riser & $\begin{array}{l}\text { Low and } \\
\text { Langley } \\
{[102]}\end{array}$ & $\begin{array}{l}\text { Vessel modelled as a rigid body and lines } \\
\text { discretized as lumped masses connected by } \\
\text { linear extensional and rotational springs }\end{array}$ & $\begin{array}{l}\text { Hybrid method was found to be nearly as accurate as fully } \\
\text { coupled time domain analysis but required only one-tenth } \\
\text { of the computational effort, even for a geometrically highly } \\
\text { nonlinear system. }\end{array}$ \\
\hline Vessel/mooring/riser & $\begin{array}{l}\text { Rodrigues } \\
\text { et al. [101] }\end{array}$ & $\begin{array}{l}\text { Vessel modelled as rigid body with six dof, } \\
\text { lines discretized as lumped masses }\end{array}$ & $\begin{array}{l}\text { The method was found to be in good agreement with fully } \\
\text { coupled time domain analysis, when used for relatively } \\
\text { shallow water depths }\end{array}$ \\
\hline Hull-tendon-riser & $\begin{array}{l}\text { Yang and } \\
\text { Kim [106] }\end{array}$ & $\begin{array}{l}\text { The mooring line/riser/tendon as elastic rod } \\
\text { connected to the hull by linear and rotational } \\
\text { springs }\end{array}$ & $\begin{array}{l}\text { Sudden disconnection of tendon causes the change of } \\
\text { stiffness and natural periods, the imbalance of forces and } \\
\text { moments of the total system, and possibly large transient } \\
\text { overshoots in tension at the moment of disconnection }\end{array}$ \\
\hline
\end{tabular}

\subsubsection{Cell Spar}

The Cell Spar was also designed by Kerr-McGee in the Red Hawk project Cell SPAR Platform. Red Hawk was installed in the Gulf of Mexico and made operational in 2004. Cell SPARs have several design features including: the Hard Tank which is made up of six cylindrical tubes that surround a seventh central tube. Each of these tubes is $6.1 \mathrm{~m}$ in diameter and contains variableballast tanks and redundant, independent cells. The middle hull 
section is basically the extension of three tubes among the seven cylindrical tubes. The section serves as a rigid connection between hard tank and keel tank. In addition, the lower section, or keel, contains the permanent ballast.

Red Hawk SPAR is renowned to be the first and only cell Spar. The separate tubes are connected by heave plates. Heave plates give the structure added stability by reducing the force transferred from ocean waves and current. Zhai et al. [111] have shown the development history, and introduced the structural forms of Cell Spar platform. According to the environmental conditions of the South China Sea and the operational requirements of a platform, the optimized selection of cell Spar platforms is studied. Finite element analysis of the Cell Spar platform by using ANSYS is conducted and the select rules of environmental load are given. Structural strength analysis of the platform under survival conditions and operation conditions are also conducted. The stress level and strength demand of overall structure and key positions are determined. Finally, the methods for Overall Structural Strength Analysis of the Cell Spar Platform are set up. Lim et al. [112] carried out experimental study on motion characteristics of the cell Spar platform.

\subsubsection{Cell-truss Spar}

Due to economic concerns, the cell and truss element has been added together in the same Spar platform by several researchers. Zhang et al. [113,114] have performed a numerical study on the hydrodynamic performances of a newly adopting cell Spar notion. They included cell-Spar combination as offshore floating structure. Experimental research along with a numerical study on the global performances of the cell-truss Spar platform was conducted by Zhang et al. [115]. Zhang et al. [116] studied the effect of coupling for the cell-truss Spar platform. The Spar mooring/riser was modelled via three methods namely, quasi-static coupled, semicoupled and coupled. The results from frequency-domain as well as time domain analyses were compared with experimental data.

\subsection{Spar platform in Malaysian waters}

Malaysia recently installed its first Spar which is a compliant floating Spar platform set up at $1330 \mathrm{~m}$ depth at the Kikeh field in 2007 [46]. The structural arrangement for this deep water installation fits into the category of truss Spar. It has been observed that only the Kebabangan field is traced in shallow water depth of around $200 \mathrm{~m}[44,117]$. All other six sedimentary basins are in deep water regions having water depths more than $1000 \mathrm{~m}$. Thus, the fixed jacket type of platform leads to expensive installation costs for the production of oil and gas. Spar platforms may provide competent solutions in these locations and sites. The Spar contains the assistances of offshore structures ensuring desirable floating behaviour of its own. Among the seven oil and gas fields in Malaysian sedimentary basins with different water depths (Table 9), the Spar platform in Kikeh field reflects the potential for success in Malaysian waters.

The Spar hull at Kikeh is $142 \mathrm{~m}$ long, with a diameter of $32 \mathrm{~m}$ and has a steel weight of approximately $12,000 \mathrm{mt}$. The topsides

Table 9

Offshore oil and gas fields in Malaysia at different water depths.

\begin{tabular}{ll}
\hline Field name & Water depth $(\mathbf{m})$ \\
\hline Kikeh & 1300 \\
Gumusut/Kakap & 1220 \\
Jangas & $>1000$ \\
Ubah Crest & $>1000$ \\
Pisangan & $>1000$ \\
Kamunsu & $>1000$ \\
Kebabangan & $>200$ \\
\hline
\end{tabular}

facilities weigh approximately $3000 \mathrm{mt}$ and provide a 25-slot wellbay for dry tree wellheads. The Kikeh development is located in offshore Block K Malaysia, which is operated by Murphy with an $80 \%$ working interest. Petronas Carigali, a wholly owned exploration and production company of Petronas, holds the remaining $20 \%$. The Kikeh area has a recoverable reserve base in excess of 400 million barrels with associated expansion ability. This Spar platform is the first one ever installed outside the Gulf of Mexico. It is the first application of tender-assisted drilling on a Spar platform. This contract increases Technip's presence in Malaysia and reinforces its leading position in deep water developments through its field-proven floating production Spar platform.

Existing sedimentary basins contribute significantly as the main sources of oil and gas, which can compensate the rising demand for these energies. Among the continental shelf offshore of Malaysian waters, deep basins are more suited to be installed by floating platforms. Especially the Sarawak basin off the East Malaysian state Sarawak and the Sabah basins off the East Malaysian state Sabah, located at ultra-deep water depths. The most challenging job is to be able to explore deep-water energy sources from the eastern continental shelf. High functioning costs and extensive technical expertise indicate the aptness of floating platforms like the Spar in this region. The newly adopted oil production project which is in the planning and construction phase is the Gumusut/Kakap project situated off the shores of Sabah at $1200 \mathrm{~m}$ water depth. This field is attempting to install the regions' first deep-water floating production system possessing a processing capacity of $150,000 \mathrm{bbl} /$ d, using 19 subsea wells. Apart from this, the offshore Sarawak basin is located at an ultra-deep water depth of $2000 \mathrm{~m}$, where other types of structures other than the compliant floating platform will not be practical or viable. Considering the water depth, structural safety and economy, it can be concluded that the floating Spar platform has immense potential in the Malaysian offshore region.

\subsection{Future research for Spar platform}

The technology of oil and gas exploration is blooming for deep water ocean deposits. There are quite few configurations of Spar platform that have been reported. In deeper waters, Spar platforms are found to be economical and efficient for drilling, production, processing and storage of ocean reserves. Although numerous studies have been accomplished on offshore floating Spar platform, there are quite few issues that are yet to be explored and investigated. Following are the important aspects required to be addresses for future work in this area:

- For precise behaviour of Spar platform consideration of mathematical model comprising platform, mooring lines and risers in one system is essential.

- Synthetic mooring lines and composite risers can be incorporated to make the structure more economical and efficient.

- Heave response of platform can be reduced by increasing sectional area at Spar bottom as an alternate approach.

- Introducing buoys on mooring line length can reduce the maximum mooring tension.

- Inclusion of wave directionality effect and higher order wave forces will make the analysis more realistic.

- Fluctuating and mean wind components act on the superstructure of Spar platform. It is a source of wave generation in substructure region. Hence it is important to model the bluff configuration of superstructure and obtain the wind induced forces on the same while the substructure experiences the hydrodynamic loading. The existing works may be extended to the wind and wave induced vibration of the Spar platform system. 
- The vortex induced vibration in the catenary mooring lines contributes cumulative fatigue damage which should be properly investigated.

- There is an ample scope to improve the solution technique of nonlinear system of dynamic equations. Accuracy and faster convergence may be achieved if an improved algorithm is adopted.

- Probabilistic risk assessment is essential for the massive and expensive Spar installations in energy exploration. Stability and serviceability limit state are required to be incorporated. For the entire structure reliability, fault tree approach may be adopted.

- Comprehensive stability analysis of Spar platform and mooring lines is essential to be studied to get proper stable configuration under long duration environment loading.

- As most of the offshore fields of Malaysia are under deep and ultra-deep water, optimal configuration of floating Spar platform is to be assessed for massive energy exploration.

\section{Conclusion}

The Malaysian energy zone is still predominantly reliant on primary energy sources such as oil and gas. The energy industry is experiencing a lot of growing energy demand (7-8\%) in this country. There is a pressing need to create newer fields and sectors for oil and gas energy exploration so as to meet the severely increasing fuel demand. The research carries out a literature survey of the up to date research knowledge on oil and gas status in Malaysia. Offshore reserves of oil and gas energy have been well investigated to enquire their projected contribution in the fuel energy sector. The primary energy exploration strategy from the Malaysian deep water region and offshore compliant floating Spar platforms for oil and gas exploration has been acquainted with. Assessment on the technical development of the Spar platform has been given. The various kinds of operational Spar platforms have been critically explored. The structural configurations of Spar structures in deep ocean environment described in various existing literature have been reviewed. This paper also attempts to address works of Spar platform subjected to various environmental loading of deepocean concerning. The Spar platform has been found as an innovative and structurally and economically suitable marine structure ideal to conduct oil and gas exploration in the deep sea. The study indicates that the Spar platform has a huge potential in the future; it is expected to greatly promote operations on the sea and stabilize production by improving technical parameters, economic concerns and other aspects. Spar platform operation and use in this Malaysian region is still at a developing stage to explore deep and ultra-deep water oil and gas. Malaysia must strive to enhance the oil and gas energy exploration sector through installing Spar platforms in its deep waters so as to enjoy greater efficiency and cost effectiveness.

\section{Acknowledgement}

The authors would like to gratefully acknowledge the University of Malaya (UM), for their support through the Grant nos. RG140-12AET and PV052/2011B.

\section{Reference}

[1] Ong HC, Mahlia TMI, Masjuki HH. A review on energy scenario and sustainable energy in Malaysia. Renewable and Sustainable Energy Reviews 2011;15:639-47.
[2] Akorede MF, Hizam H, Pouresmaeil E. Distributed energy resources and benefits to the environment. Renewable and Sustainable Energy Reviews 2010;14:724-34.

[3] Falcão AFdO. Wave energy utilization: a review of the technologies. Renewable and Sustainable Energy Reviews 2010;14:899-918.

[4] Güney MS, Kaygusuz K. Hydrokinetic energy conversion systems: a technology status review. Renewable and Sustainable Energy Reviews 2010;14:2996-3004.

[5] Yüksel I. Hydropower for sustainable water and energy development. Renewable and Sustainable Energy Reviews 2010;14:462-9.

[6] O'Rourke F, Boyle F, Reynolds A. Tidal current energy resource assessment in Ireland: current status and future update. Renewable and Sustainable Energy Reviews 2010;14:3206-12.

[7] Balamurugan P, Ashok S, Jose TL. Optimal operation of biomass/wind/PV hybrid energy system for rural areas. International Journal of Green Energy 2009;6:104-16.

[8] Ahmad S, Kadir MZAA, Shafie S. Current perspective of the renewable energy development in Malaysia. Renewable and Sustainable Energy Reviews 2011;15:897-904.

[9] Ninth (9th) Malaysia plan 2006-2010. Chapter 19, Sustainable energy development; 2009. p. 393-411.

[10] Oh TH, Pang SY, Chua SC. Energy policy and alternative energy in Malaysia: issues and challenges for sustainable growth. Renewable and Sustainable Energy Reviews 2010;14:1241-52.

[11] Chen F, Lu S-M, Tseng K-T, Lee S-C, Wang E. Assessment of renewable energy reserves in Taiwan. Renewable and Sustainable Energy Reviews 2010;14:2511-28.

[12] Cuvilas CA, Jirjis R, Lucas C. Energy situation in Mozambique: a review. Renewable and Sustainable Energy Reviews 2010;14:2139-46.

[13] Erdem ZB. The contribution of renewable resources in meeting Turkey's energy-related challenges. Renewable and Sustainable Energy Reviews 2010;14:2710-22.

[14] Sheikh MA. Energy and renewable energy scenario of Pakistan. Renewable and Sustainable Energy Reviews 2010;14:354-63.

[15] Toklu E, Güney MS, IsIk M, ComaklI O, Kaygusuz K. Energy production, consumption, policies and recent developments in Turkey. Renewable and Sustainable Energy Reviews 2010;14:1172-86.

[16] Tsai W-T. Energy sustainability from analysis of sustainable development indicators: a case study in Taiwan. Renewable and Sustainable Energy Reviews 2010;14:2131-8.

[17] Valkila N, Saari A. Urgent need for new approach to energy policy: the case of Finland. Renewable and Sustainable Energy Reviews 2010;14:2068-76.

[18] Stigson P, Dotzauer E, Yan J. Climate and energy policy evaluation in terms of relative industrial performance and competitiveness. International Journal of Green Energy 2009;6:450-65.

[19] Genoud S, Lesourd J-B. Characterization of sustainable development indicators for various power generation technologies. International Journal of Green Energy 2009;6:257-67.

[20] Deilmann C, Bathe K-J. A holistic method to design an optimized energy scenario and quantitatively evaluate promising technologies for implementation. International Journal of Green Energy 2009;6:1-21.

[21] Arabian A. Synergy in green power production methods and siting. International Journal of Green Energy 2010;7:143-52.

[22] Finkl CW, Charlier R. Electrical power generation from ocean currents in the Straits of Florida: some environmental considerations. Renewable and Sustainable Energy Reviews 2009;13:2597-604.

[23] Grabbe M, Lalander E, Lundin S, Leijon M. A review of the tidal current energy resource in Norway. Renewable and Sustainable Energy Reviews 2009;13:1898-909.

[24] Guo D-G, Zhang X-Y, Shao H-B, Bai Z-K, Chu L-Y, Shangguan T-L, et al. Energy plants in the coastal zone of China: category, distribution and development. Renewable and Sustainable Energy Reviews 2011;15:2014-20.

[25] Martín Mederos AC, Medina Padrón JF, Feijóo Lorenzo AE. An offshore wind atlas for the Canary Islands. Renewable and Sustainable Energy Reviews 2011;15:612-20.

[26] Matos FB, Camacho JR, Rodrigues P, Guimarães Jr. SC. A research on the use of energy resources in the Amazon. Renewable and Sustainable Energy Reviews 2011;15:3196-206.

[27] Mostafaeipour A. Feasibility study of offshore wind turbine installation in Iran compared with the world. Renewable and Sustainable Energy Reviews 2010;14:1722-43.

[28] Zabihian F, Fung AS. Review of marine renewable energies: case study of Iran. Renewable and Sustainable Energy Reviews 2011;15:2461-74.

[29] Wang S, Yuan P, Li D, Jiao Y. An overview of ocean renewable energy in China. Renewable and Sustainable Energy Reviews 2011;15:91-111.

[30] Peidong Z, Yanli Y, Jin S, Yonghong Z, Lisheng W, Xinrong L. Opportunities and challenges for renewable energy policy in China. Renewable and Sustainable Energy Reviews 2009;13:439-49.

[31] Liu L-Q, Liu C-X, Sun Z-Y, Han R-C. The development and application practice of neglected tidal energy in China. Renewable and Sustainable Energy Reviews 2011;15:1089-97.

[32] Li D, Wang S, Yuan P. An overview of development of tidal current in China: energy resource, conversion technology and opportunities. Renewable and Sustainable Energy Reviews 2010;14:2896-905.

[33] Zhixin W, Chuanwen J, Qian A, Chengmin W. The key technology of offshore wind farm and its new development in China. Renewable and Sustainable Energy Reviews 2009;13:216-22. 
[34] Menicou M, Vassiliou V. Prospective energy needs in Mediterranean offshore aquaculture: renewable and sustainable energy solutions. Renewable and Sustainable Energy Reviews 2010;14:3084-91.

[35] de Alegría IM, Martín JL, Kortabarria I, Andreu J, Ereño PI. Transmission alternatives for offshore electrical power. Renewable and Sustainable Energy Reviews 2009;13:1027-38.

[36] Rourke FO, Boyle F, Reynolds A. Marine current energy devices: current status and possible future applications in Ireland. Renewable and Sustainable Energy Reviews 2010;14:1026-36.

[37] Jameel M, Ahmad S, Islam ABMS, Jumaat MZ. Nonlinear analysis of fully coupled integrated spar-mooring line system. In: ISOPE, editor. The 21st international offshore and polar engineering conference; 2011. p. 198-205.

[38] Islam ABMS, Jameel M, Jumaat MZ. Effect of time elapse after wave hitting on coupled Spar platform. International Journal of Physical Sciences 2011;6:2671-80.

[39] Glanville RS, Halkyard JE, Davies RL, Frimm F. Neptune project: Spar history and design considerations. In: Proceedings of the twenty-ninth offshore technology conference. OTC 8382, Houston, Texas, USA; 1997.

[40] Halkyard JE. Status of Spar platforms for deepwater production systems. In: Proceedings of the sixth international offshore and polar engineering conference. vol. 1. International Society of Offshore and Polar Engineers (ISOPE): Los Angeles, California, USA; 1996. p. 262-72.

[41] Islam ABMS, Jameel M, Ahmad S, Jumaat MZ, Kurian VJ. Structural behaviour of fully coupled spar-mooring system under extreme wave loading. Journal of Civil Engineering and Management, in press.

[42] Jameel M, Islam ABMS, Khaleel M, Jumaat MZ. Nonlinear finite element analysis of spar platform. Advanced Science Letters 2012;13:723-6.

[43] Montasir OA, Kurian VJ. Effect of slowly varying drift forces on the motion characteristics of truss spar platforms. Ocean Engineering 2011;38: 1417-29.

[44] Islam ABMS, Jameel M, Jumaat MZ. Oil and gas energy potential at Malaysian seabed and Spar platform for deepwater installation. International Journal of Green Energy 2012;9:111-20.

[45] Islam ABMS, Jameel M, Jumaat MZ, Salam MA. Energy resources at Malaysian sedimentary basins and spar platform as deep sea structure. In: ICMET, editor. 3rd international conference on mechanical and electrical technology (ICMET 2011). vol. 2; 2011. p. 615-20.

[46] Islam ABMS, Jameel M, Jumaat MZ, Shirazi SM. Spar platform at deep water region in Malaysian sea. International Journal of the Physical Sciences 2011;6:6872-81.

[47] Jameel M, Ahmad S, Islam ABMS, Jumaat MZ. Nonlinear dynamic analysis of coupled spar platform. Journal of Civil Engineering and Management, in press.

[48] Wang Y, Yang J-M, Hu Z-Q, Xiao L-F. Theoretical research on hydrodynamics of a geometric Spar in frequency- and time-domains. Journal of Hydrodynamics, Series B 2008;20:30-8.

[49] Kurian VJ, Wong BS, Montasir OAA. Frequency domain analysis of truss spar platform. In: Proceedings of the international conference on construction and building technology (ICCBT); 2008. p. C-(21)-235-44.

[50] US Energy Information Administration. Malaysia energy data, statistics and analysis-oil, gas, electricity, coal; 2009.

[51] Rahman Mohamed A, Lee KT. Energy for sustainable development in Malaysia: energy policy and alternative energy. Energy Policy 2006;34:2388-97.

[52] A.F. Hasan, Energy efficiency and renewable energy in Malaysia. In: Malaysia's Energy Commission, Selangor, Malaysia; 2009.

[53] NEB. National Energy Balance 2008. Malaysia Energy centre. Selangor, Malaysia; 2009.

[54] US Energy Information Administration. Malaysia energy data, statistics and analysis-oil, gas, electricity, coal; 2010.

[55] Malaysian Natural Gas. In: International Energy Statistics: 2010. http:// www.eia.gov/countries/country-data.cfm?fips $=$ MY.

[56] Jameel M. Non-linear dynamic analysis and reliability assessment of deepwater floating structure. Thesis. Indian institute of technology; 2008.

[57] Reddy DV, Arockiasamy M. Offshore Structures. Malabar, Florida: Krieger Publishing Company; 1991.

[58] Clauss G., Lehmann E., Ostergaard C. Offshore structures. Conceptual design and hydromechanics. vol. 1. Berlin: Springer-Verlag; 1992 (Translated by M.J. Shields).

[59] Uddin MA, Jameel M, Razak HA, Islam ABMS. Response prediction of offshore floating structure using artificial neural network. Advanced Science Letters 2012;14:186-9.

[60] Jameel M, Ahmad S. Fatigue reliability assessment of coupled spar-mooring system. In: ASME, editor. ASME 30th international conference on ocean, offshore and arctic engineering, (OMAE 2011-49687). Rotterdam, The Netherlands; 2011.

[61] Mandal S. Nonlinear coupled dynamic response of offshore spar platforms under regular sea waves: By Agarwal AK, Jain AK editors. Ocean Engineering 2003; 30: 517-55. Ocean Engineering 2004; 31: 791-3.

[62] Islam ABMS, Hussain RR, Jameel M, Jumaat MZ. Non-linear time domain analysis of base isolated multi-storey building under site specific bi-directional seismic loading. Automation in Construction 2012;22:554-66.

[63] Jameel M, Saiful Islam ABM, Hussain RR, Khaleel M, Zaheer MM. Optimum structural modelling for tall buildings. The Structural Design of Tall and Special Buildings 2012, http://dx.doi.org/10.1002/tal.1004.

[64] Rahman MA, Mizutani N, Kawasaki K. Numerical modelling of dynamic responses and mooring forces of submerged floating breakwater. Coasta Engineering 2006;53:799-815.
[65] Zhou ZX, Lo EYM, Tan SK. Effect of shallow and narrow water on added mass of cylinders with various cross-sectional shapes. Ocean Engineering 2005;32:1199-215.

[66] Wichers JEW, Huijismans RHM. The contribution of hydrodynamic damping induced by mooring chains on low frequency motions. In: Proceedings of the offshore technology conference; 1990. p. 171-82.

[67] Shah AA, Umar A, Siddiqui NA. A methodology for assessing the reliability of taut and slack mooring systems against instability. Ocean Engineering 2005;32:1216-34.

[68] Ran Z, Kim MH, Niedzwecki JM, Johnson RP. Response of a spar platform in random waves and currents (experiment vs. theory). International Journal of Offshore and Polar Engineering 1996;6:27-34.

[69] Jha AK, de Jong PR, Winterstein SR. Motion of spar buoy in random seas: comparing predictions and model test results. Behaviour of Offshore Structures 1997;97(2):333-47.

[70] Ran Z, Kim MH. Nonlinear coupled responses of a tethered spar platform in waves. International Journal of Offshore and Polar Engineering 1997;7: 111-8.

[71] Chen XH, Zhang J., Ma W. Coupled time-domain analysis of the response of a spar and its mooring system. In: Proceedings of the ninth international offshore and polar engineering conference. 1999, p. 293-300.

[72] Zhang H, Sun Z, Yang J, Gao M. Investigation on optimization design of equivalent water depth truncated mooring system. Science in China Series G: Physics, Mechanics and Astronomy 2009;52:277-92.

[73] Stansberg CT, Yttervik R, Oritsland O, Kleiven G. Hydrodynamic model test verification of a floating platform system in $3000 \mathrm{~m}$ water depth. In: Proceedings of the 19th international conference on offshore mechanics and arctic engineering (OMAE). ; 2000. p. 325-33.

[74] Chen XH, Zhang J, Johnson P, Irani M. Studies on the dynamics of truncated mooring line. In: Proceedings of the tenth international offshore and polar engineering conference. vol. 2; 2000. p. 94-101.

[75] Ormberg H, Stansberg CT, Yttervik R. Integrated vessel motion and mooring analysis applied in hybrid model testing. In: Proceedings of the nineth international offshore and polar engineering conference. vol. 1; 1999. p. 339-46.

[76] Ran Z, Kim MH, Zheng W. Coupled dynamic analysis of a moored spar in random waves and currents (time-domain versus frequency-domain analysis). Journal of Offshore Mechanics and Arctic Engineering 1999;121: 194-200.

[77] Ma QW, Patel MH. On the non-linear forces acting on a floating spar platform in ocean waves. Applied Ocean Research 2001;23:29-40.

[78] Chen X, Zhang J, Ma W. On dynamic coupling effects between a spar and its mooring lines. Ocean Engineering 2001;28:863-87.

[79] Agarwal AK, Jain AK. Nonlinear coupled dynamic response of offshore Spar platforms under regular sea waves. Ocean Engineering 2003;30: 517-51.

[80] Umar A, Datta TK. Nonlinear response of a moored buoy. Ocean Engineering 2003;30:1625-46.

[81] Anam I, Roesset JM, Niedzwecki JM. Time domain and frequency domain analysis of Spar platforms. In: Proceedings of the thirteenth international offshore and polar engineering conference, international society of offshore and polar engineers (ISOPE); 2003. p. 240-7.

[82] Anam I. Non-linear dynamic analysis and reliability assessment of deepwater floating structure. Thesis. Texas: A \& M University; 2000.

[83] Mazaheri S, Downie MJ. Response-based method for determining the extreme behaviour of floating offshore platforms. Ocean Engineering 2005;32:363-93.

[84] Chernetsov VA, Karlinsky SL. Ice-resistant spar-type platform for middle sea depth. In: ISOPE, editor. The 16 th international offshore and polar engineering conference; 2006. p. 614-9.

[85] Ma W, Lee MY, Zou J, Huang E. Deepwater nonlinear coupled analysis tool. In: Proceedings of the offshore technology conference; 2000. p. 1-11.

[86] Ormberg H, Larsen K. Coupled analysis of floater motion and mooring dynamics for a turret-moored ship. Applied Ocean Research 1998;20:55-67.

[87] Irani MB, Rouckout T, Johnson RP. Dynamics of a Spar Platform. In: ISOPE, editor. The 10th international offshore and polar engineering conference; 2000. p. 261-8.

[88] Colby C, Sodahl N, Katla E, Okkenhaug S. Coupling effects for a deepwater spar. In: Proceedings of the offshore technology conference; 2000.

[89] Gupta H, Finn L, Weaver T. Effects of spar coupled analysis. In: Proceedings of the offshore technology conference; 2000. p. 1-10.

[90] Chaudhury G., Ho C.-Y. Coupled dynamic analysis of platforms, risers, and moorings. In: Proceedings of the offshore technology conference; 2000.

[91] Chaudhary G. A new method for coupled dynamic analysis of platforms. In: Proceedings of the eleventh international offshore and polar engineering conference; 2001. p. 444-8.

[92] Astrup OC, Nestegård A, Ronæs SM, Sødahl N. Coupled analysis strategies for deepwater spar platforms. In: Proceedings of the eleventh international offshore and polar engineering conference; 2001. pp. 449-56.

[93] Kim MH, Ward EG, Harnig R. Comparison of Numerical models for the capability of hull/mooring/riser coupled dynamic analysis for spars and TLPS in deep and ultra deep water. In: Proceedings of the eleventh international offshore and polar engineering conference; 2001. p. 474-9.

[94] Zhang X, Zou J. Coupled effects of risers/supporting guide frames on spar responses. In: Proceedings of the twelfth international offshore and polar engineering conference; 2002. p. 231-6. 
[95] Tahar A, Ran Z, Kim MH. Hull/mooring/riser coupled spar motion analysis with buoyancy-can effect. In: Proceedings of the twelfth international offshore and polar engineering conference; 2002. p. 223-30.

[96] Ding Y, Kim M, Chen X, Zhang J. In: Zhang J, Mercier RS, editors. A numerical code (COUPLE6D) for coupled dynamic analysis of moored offshore structures, 132. Houston, Texas, USA: ASCE; 2003. p. 12.

[97] Koo BJ, Kim MH, Randall RE. The effect of nonlinear multi-contact coupling with gap between risers and guide frames on global spar motion analysis. Ocean Engineering 2004;31:1469-502.

[98] Yung T-W, Sandstrom RE, Slocum ST, Ding ZJ, Lokken RT. Advancement of spar VIV prediction. In: Proceedings of the offshore technology conference; 2004. p. 1-6.

[99] Kim MH, Koo BJ, Mercier RM, Ward EG. Vessel/mooring/riser coupled dynamic analysis of a turret-moored FPSO compared with OTRC experiment. Ocean Engineering 2005;32:1780-802.

[100] Garrett DL. Coupled analysis of floating production systems. Ocean Engineering 2005;32:802-16.

[101] Rodrigues MV, Correa FN, Jacob BP. Implicit domain decomposition methods for coupled analysis of offshore platforms. Communications in Numerical Methods in Engineering 2007;23:599-621.

[102] Low YM, Langley RS. A comparison of methods for the couple analysis of floating structures. In: Proceedings of the 26th international conference on offshore mechanics and arctic engineering (OMAE); 2007.

[103] Tahar A, Kim MH. Coupled-dynamic analysis of floating structures with polyester mooring lines. Ocean Engineering 2008;35:1676-85.

[104] Low YM, Langley RS. A hybrid time/frequency domain approach for efficient coupled analysis of vessel/mooring/riser dynamics. Ocean Engineering 2008;35:433-46.

[105] Low YM. Prediction of extreme responses of floating structures using a hybrid time/frequency domain coupled analysis approach. Ocean Engineering 2008;35:1416-28.

[106] Yang CK, Kim MH. Transient effects of tendon disconnection of a TLP by hull-tendon-riser coupled dynamic analysis. Ocean Engineering 2010;37: 667-77.

[107] Kim MH, Ran Z, Zheng W. Hull/mooring coupled dynamic analysis of a truss spar in time domain. International Journal of Offshore and Polar Engineering 2001;11:42-54.

[108] Hu ZQ, Cui WC, Xiao LF, Yang JM. Research on collision mechanisms for a ship colliding with a spar platform. In: Proceedings of the 26th international conference on offshore mechanics and arctic engineering. vol 2; 2007. p. 69-77.

[109] Liu Z, Teng B, Ning D-Z, Gou Y. Wave-current interactions with threedimensional floating bodies. Journal of Hydrodynamics, Series B 2010;22: 229-40.

[110] Sadeghi K, Incecik A, Downie MJ. Response analysis of a truss spar in the frequency domain. Journal of Marine Science and Technology 2004;8: 126-37.

[111] Zhai GJ, Qi K, Kang HG. Overall structural strength analysis of the cell spar platform. In: Proceedings of the Chinese-German joint symposium on hydraulic and ocean engineering; 2008. p. 579-83.

[112] Lim SJ, Rho JB, Choi HS. An experimental study on motion characteristics of cell spar platform. In: Proceedings of the fifteenth international offshore and polar engineering conference-2005. vol. 1; 2005. p. 233-7.

[113] Zhang F, Yang J-M, Li R-P, Chen G. Numerical investigation on the hydrodynamic performances of a new spar concept. Journal of Hydrodynamics, Series B 2007;19:473-81.

[114] Zhang F, Yang JM, Li RP, Chen G. Numerical study on the hydrodynamic behavior of a new cell-truss spar platform. In: Proceedings of the 26th international conference on offshore mechanics and arctic engineering. vol. 1; 2007. p. 93-102.

[115] Zhang F, Yang JM, Li RP, Chen G. Numerical and experimental research on the global performances of cell-truss spar platform. China Ocean Engineering 2007;21:561-76.

[116] Zhang F, Yang J-M, Li R-P, Chen G. Coupling effects for cell-truss spar platform: comparison of frequency- and time-domain analyses with model tests. Journal of Hydrodynamics, Series B 2008;20:424-32.

[117] Jameel M, Islam ABMS, Salman FA, Khaleel M, Jumaat MZ. Wave data for shallow and deep water sedimentary basins of Malaysia. Advanced Science Letters 2012;14:360-4.

[118] PETRONAS. PETRONAS Oil \& Gas Company. Petroliam Nasional Berhad; 2010.

[119] Net Resources International. Offshore technology, SPG Media Limited; 2011

[120] Agarwal AK, Jain AK. Dynamic behavior of offshore spar platforms under regular sea waves. Ocean Engineering 2003;30:487-516.

[121] Sarkar I, Roesset JM., Variability of results of dynamic analysis of spars. In Proceedings of the fourteenth international offshore and polar engineering conference; 2004. p. 650-4. 